\title{
The Land Surface Climatology of the Community Land Model Coupled to the NCAR Community Climate Model*
}

\author{
Gordon B. Bonan, Keith W. Oleson, Mariana Vertenstein, and Samuel Levis \\ National Center for Atmospheric Research, Boulder, Colorado \\ Xubin Zeng \\ Institute of Atmospheric Physics, University of Arizona, Tucson, Arizona \\ YongJiU DAi AND Robert E. Dickinson \\ School of Earth and Atmospheric Sciences, Georgia Institute of Technology, Atlanta, Georgia \\ ZONG-LIANG YANG \\ Department of Geological Sciences, University of Texas at Austin, Austin, Texas
}

(Manuscript received 13 December 2001, in final form 29 April 2002)

\section{ABSTRACT}

\begin{abstract}
The land surface parameterization used with the community climate model (CCM3) and the climate system model (CSM1), the National Center for Atmospheric Research land surface model (NCAR LSM1), has been modified as part of the development of the next version of these climate models. This new model is known as the community land model (CLM2). In CLM2, the surface is represented by five primary subgrid land cover types (glacier, lake, wetland, urban, vegetated) in each grid cell. The vegetated portion of a grid cell is further divided into patches of up to 4 of 16 plant functional types, each with its own leaf and stem area index and canopy height. The relative area of each subgrid unit, the plant functional type, and leaf area index are obtained from 1-km satellite data. The soil texture dataset allows vertical profiles of sand and clay. Most of the physical parameterizations in the model were also updated. Major model differences include: 10 layers for soil temperature and soil water with explicit treatment of liquid water and ice; a multilayer snowpack; runoff based on the TOPMODEL concept; new formulation of ground and vegetation fluxes; and vertical root profiles from a global synthesis of ecological studies. Simulations with CCM3 show significant improvements in surface air temperature, snow cover, and runoff for CLM2 compared to LSM1. CLM2 generally warms surface air temperature in all seasons compared to LSM1, reducing or eliminating many cold biases. Annual precipitation over land is reduced from $2.35 \mathrm{~mm} \mathrm{day}^{-1}$ in LSM1 to $2.14 \mathrm{~mm} \mathrm{day}^{-1}$ in CLM2. The hydrologic cycle is also different. Transpiration and ground evaporation are reduced. Leaves and stems evaporate more intercepted water annually in CLM2 than LSM1. Global runoff from land increases from $0.75 \mathrm{~mm}$ day ${ }^{-1}$ in LSM1 to $0.84 \mathrm{~mm}^{-1 a y}{ }^{-1}$ in CLM2. The annual cycle of runoff is greatly improved in CLM2, especially in arctic and boreal regions where the model has low runoff in cold seasons when the soil is frozen and high runoff during the snowmelt season. Most of the differences between CLM2 and LSM1 are attributed to particular parameterizations rather than to different surface datasets. Important processes include: multilayer snow, frozen water, interception, soil water limitation to latent heat, and higher aerodynamic resistances to heat exchange from ground.
\end{abstract}

\section{Introduction}

The National Center for Atmospheric Research Land Surface Model (NCAR LSM) is the land surface pa-

* The National Center for Atmospheric Research is sponsored by the National Science Foundation.

Corresponding author address: Dr. Gordon Bonan, NCAR CGD, P.O. Box 3000, Boulder, CO 80307-3000.

E-mail: bonan@ucar.edu rameterization used with the community climate model (CCM3) and the climate system model (CSM1). Since the documentation of this model by Bonan (1996, 1998), the land biogeophysical parameterizations have been reevaluated and changed as part of the development of the next version of the climate model. In particular, Zeng et al. (2002) developed a new biogeophysical parameterization called the common land model. This model combines many of the features of the BATS (Dickinson et al. 1993), NCAR LSM (Bonan 1996), and IAP94 (Dai and Zeng 1997) land models. It significantly reduces 
the cold summer surface air temperature bias in CCM3 and CSM1 by reducing latent heat flux and increasing sensible heat flux, improves the annual cycle of runoff, and better simulates snow mass (Zeng et al. 2002).

While the new biogeophysical parameterizations were being developed, NCAR LSM continued to be developed for carbon cycle and vegetation dynamics studies. NCAR LSM was originally developed to link the exchanges of energy, water, and $\mathrm{CO}_{2}$ and was an outgrowth of earlier work with a similar model for boreal forests (Bonan 1991a-c, 1992, 1993a-c). Global simulations of NCAR LSM coupled to CCM3 showed that simple physiological and ecological assumptions result in reasonable simulation of land-atmosphere $\mathrm{CO}_{2}$ exchange over a wide range of climates and ecosystems (Bonan 1995a; Craig et al. 1998). More recent work has focused on coupling with ecosystem and vegetation dynamics models. In particular, the model represents vegetation not as biomes (e.g., savanna) but rather as patches of plant functional types (e.g., grasses, trees). This is because many of the leaf physiological and plant allocation parameters used in ecological models cannot be measured for biomes but can be measured for individual plant types. Plant functional types reduce the complexity of species diversity in ecological function to a few key plant types and provide a critical link to ecosystem processes and vegetation dynamics (Woodward and Cramer 1996; Smith et al. 1997). However, in NCAR LSM the types of plants in a grid cell and their abundance, leaf and stem area, and height are obtained by classifying the grid cell as one of 28 biomes. To better interface with ecological models and to take advantage of high-resolution satellite data products, NCAR LSM was changed to allow plant type, abundance, leaf area, stem area, and height to be input to the model for each grid cell (Oleson and Bonan 2000; Bonan et al. 2002).

These developments in biogeophysics, carbon cycle, and vegetation dynamics have been merged into a new model of land surface processes for climate models: the community land model (CLM2). This paper documents the effect of changes in model biogeophysics on the simulated climate. The carbon cycle and vegetation dynamics of the model will be described elsewhere. Three versions of the land model coupled to CCM3 are compared: LSM1, the original NCAR LSM; LSM2, an intermediate version of NCAR LSM that retains most of its biogeophysics but includes new surface datasets and modifications for coupling to a dynamic global vegetation model; and CLM2, the final model that merges the features of LSM2 with many of the biogeophysical parameterizations of the common land model.

\section{Methods}

Simulations of 17-yr length were performed with each of the three land models coupled to a version of CCM3. CCM3 is a spectral atmospheric model with T42 trun- cation (approximately $2.8^{\circ}$ horizontal resolution), 18 vertical levels, and a 20-min time step (Kiehl et al. 1996, 1998). Simulations used observed sea surface temperatures for the period September 1978-December 1995. The models were initialized with temperatures of $10^{\circ} \mathrm{C}$, no snow or canopy water, and volumetric soil water content of $0.3 \mathrm{~mm}^{3} \mathrm{~mm}^{-3}$ over land. Lakes and wetlands were initialized to $4^{\circ} \mathrm{C}$. Glaciers were initialized to $-23^{\circ} \mathrm{C}$ and $1000 \mathrm{~kg} \mathrm{~m}^{-2}$ of snow. Only the last $12 \mathrm{yr}$ of the simulations (i.e., for the period 1984-95) were analyzed to allow a 5-yr spinup of soil water and temperature. The control simulation with LSM1 replicates the temperature and precipitation biases reported by Bonan (1998).

\section{a. LSM1}

LSM1 is the NCAR LSM as described by Bonan (1996, 1998). The model simulates the exchange of energy, water, momentum, and carbon between the surface and the atmosphere. Vegetation effects are included by allowing for 12 plant functional types (PFTs) that differ in plant physiology (leaf optical properties, stomatal physiology, leaf dimension) and vegetation structure (height, roughness length, displacement height, root profile, monthly leaf and stem area). Multiple PFTs can co-occur in a grid cell so that, for example, a mixed broadleaf deciduous and needleleaf evergreen forest consists of patches of broadleaf deciduous trees, needleleaf evergreen trees, and bare ground. Each patch, while co-occurring in a grid cell, is a separate column upon which energy, water, and carbon calculations are performed. Thus, plants do not compete for light and water. The abundance of PFTs in a grid cell is specified from one of 28 different biomes (Bonan 1995a, 1996). Lakes and wetlands, if present, form additional patches. Soil effects are included by allowing thermal and hydraulic properties to vary depending on sand and clay content. Soils also differ in color, which affects soil albedo. Required surface input data for each grid cell include a biome type (which determines the patch fractions for each PFT), the fraction of the grid cell covered by lakes, the fraction covered by wetlands, soil texture (percent sand, silt, and clay), and soil color.

Bonan (1996) documents the model, and Bonan (1998) describes the climatology of the model coupled to the CCM3. Comparisons with tower flux data show that the model reasonably simulates surface fluxes in several boreal forest (Bonan et al. 1997) and tundra (Lynch et al. 1999a) sites. The model has been used to study land-atmosphere $\mathrm{CO}_{2}$ exchange (Bonan 1995a; Craig et al. 1998), the effect of lakes and wetlands on climate (Bonan 1995b), the effect of vegetation and soil (Kutzbach et al. 1996) and lakes and wetlands (Coe and Bonan 1997; Carrington et al. 2001) on the African monsoon in the middle Holocene, the effect of soil water on floods and droughts in the Mississippi River basin (Bonan and Stillwell-Soller 1998), and the effects of 
Primary Land Cover

\begin{tabular}{|c|c|c|c|c|}
\hline \multicolumn{2}{|c|}{$\begin{array}{l}\text { glacier } \\
16.7 \%\end{array}$} & \multirow{4}{*}{$\begin{array}{c}\text { vegetated } \\
50 \%\end{array}$} & \multirow{4}{*}{$\begin{array}{c}\text { needleleaf } \\
\text { evergreen tree, } \\
\text { temperate } \\
45 \%\end{array}$} & $\begin{array}{c}\text { broadleaf } \\
\text { deciduous tree, }\end{array}$ \\
\hline \multirow{2}{*}{\multicolumn{2}{|c|}{$\begin{array}{l}\text { lake } \\
16.7 \%\end{array}$}} & & & $25 \%$ \\
\hline & & & & crop \\
\hline $\begin{array}{l}\text { wet- } \\
\text { land } \\
8.3 \%\end{array}$ & $\begin{array}{l}\text { urban } \\
8.3 \%\end{array}$ & & & $\begin{array}{c}\text { bare ground } \\
15 \%\end{array}$ \\
\hline
\end{tabular}

FIG. 1. Representation of land cover heterogeneity in LSM2 and CLM2 for a hypothetical grid cell. The grid cell is divided into five primary land cover types. The vegetated portion is further divided into up to four types of plants. Bare ground is represented by a patch with no vegetation. temperate deforestation on climate (Bonan 1997, 1999). The model has been extensively used for arctic studies (Lynch et al. 1998, 1999a,b, 2001; Tilley and Lynch 1998; Lynch and Wu 2000; Wu and Lynch 2000; Beringer et al. 2001).

In their documentation of the common land model, Zeng et al. (2002) used a new soil color dataset. For consistency among models and to allow comparison with Zeng et al. (2002), we used their soil color dataset for the LSM1, LSM2, and CLM2 simulations. The major difference from the LSM1 dataset is removal of the ninth soil color class, used in the Sahara Desert and Arabian Peninsula, which was responsible for the high albedos and pronounced cold bias noted by Bonan (1998).

\section{b. $L S M 2$}

In LSM1, the geography of PFTs and the structure of vegetation (the height, roughness length, displacement height, and leaf and stem area of each PFT) are based on biomes. The type of biome determines the composition of the vegetation (i.e., the PFTs and their abundance). The PFT determines vegetation structure. This is because the high-spatial-resolution datasets needed to derive PFT composition and structure were not available during the development of LSM1. Direct specification of land cover in terms of PFTs is preferred over the use of biomes because of its more accurate depiction of spatial heterogeneity and the ability to separately specify vegetation composition and structure.

In LSM2, PFTs are inferred from 1-km satellite data. Oleson and Bonan (2000) describe this methodology for a region of the boreal forest. Bonan et al. (2002) describe the global implementation. The PFT determines plant physiology while vegetation structure is direct input to each grid cell for each PFT. This also allows the model to interface with models of ecosystem processes and vegetation dynamics such as the Lund-Potsdam-Jena (LPJ) dynamic global vegetation model (Sitch 2000; Cramer et al. 2001; McGuire et al. 2001). LPJ also uses PFTs to simulate the carbon cycle and vegetation dynamics, changing over time the structure and composition of patches of PFTs within a grid cell in response to disturbance (e.g., fire) and climate change. LSM2 is a restructuring of LSM1 to meet these objectives.

In LSM2, a grid cell is divided into five primary land cover types: glacier, lake, wetland, urban, and vegetation (Fig. 1). An urban land cover is included so that future versions of the model can study urbanization, but currently the urban cover is zero. The vegetated portion of a grid cell is further divided into patches of up to 4 of 16 PFTs, each with its own leaf area index, stem area index, and canopy top and bottom heights. Not all grid cells contain four PFTs. Homogenous vegetation may have fewer PFTs (e.g., one) than mixed vegetation (e.g., four). Bare ground is represented not as a primary land cover type, but rather as an unvegetated patch occurring among the PFTs.

As described by Bonan et al. (2002), $0.5^{\circ}$ maps of the abundance of seven primary PFTs (needleleaf evergreen or deciduous tree, broadleaf evergreen or deciduous tree, shrub, grass, crop) were derived from the 1-km International Geosphere-Biosphere Program Data and Information System (IGBP DISCover) dataset (Loveland et al. 2000) and the 1-km University of Maryland tree cover dataset (DeFries et al. 1999, 2000a,b). Temperature and precipitation were used to distinguish arctic, boreal, temperate, and tropical plants, $\mathrm{C}_{3}$ and $\mathrm{C}_{4}$ grasses, and evergreen and deciduous shrubs. Monthly leaf area index for each PFT in each $0.5^{\circ}$ grid cell was obtained from 1-km Advanced Very High Resolution Radiometer (AVHRR) red and near-infrared reflectances for April 1992-March 1993 (Bonan et al. 2002). Stem area index, canopy top height, and canopy bottom height were based on the LSM1 values prescribed for each PFT (Bonan et al. 2002). Physiological parameters for the 16 PFTs were obtained from the 12 LSM1 PFTs (Bonan 1996) so that although the list of PFTs expanded, no new physiologies were introduced.

Coupling with the LPJ dynamic global vegetation model (Sitch 2000; Cramer et al. 2001; McGuire et al. 
TABLE 1. Surface data required for LSM2 and CLM2, their base spatial resolution, and method of aggregation to the model's grid.

\begin{tabular}{|c|c|c|c|}
\hline Surface field & Resolution & Source & Aggregation method \\
\hline Percent glacier & $0.5^{\circ}$ & Bonan et al. (2002) & Area average \\
\hline Percent lake & $1^{\circ}$ & LSM1 & Area average \\
\hline Percent wetland & $1^{\circ}$ & LSM1 & Area average \\
\hline Percent sand, percent clay & $5-\min$ & $\begin{array}{l}\text { IGBP dataset of } 4931 \text { soil map- } \\
\text { ping units and their sand and } \\
\text { clay content for each soil layer }\end{array}$ & $\begin{array}{l}\text { Soil mapping unit with greatest } \\
\text { areal extent in grid cell }\end{array}$ \\
\hline Soil color & $2.8^{\circ}(\mathrm{T} 42)$ & $\begin{array}{l}\text { Zeng et al. (2002) dataset of } \\
\text { eight color classes without } \\
\text { brightened soil over the Sahara } \\
\text { Desert and Arabian Peninsula }\end{array}$ & $\begin{array}{l}\text { Soil color class with greatest are- } \\
\text { al extent in grid cell }\end{array}$ \\
\hline PFTs (percent of vegetated land) & $0.5^{\circ}$ & Bonan et al. (2002) & $\begin{array}{l}\text { Area average, choosing four most } \\
\text { abundant PFTs }\end{array}$ \\
\hline $\begin{array}{l}\text { Monthly leaf and stem area in- } \\
\text { dex }\end{array}$ & $0.5^{\circ}$ & Bonan et al. (2002) & Area average \\
\hline Canopy height (top, bottom) & $0.5^{\circ}$ & Bonan et al. (2002) & Area average \\
\hline
\end{tabular}

2001) necessitated three changes in plant physiology from LSM1. First, roughness length and displacement height were changed to proportions of canopy top height because plant height changes during vegetation dynamics. These ratios were obtained from LSM1 values prescribed for each PFT and are similar to the values of 0.1 and 0.7 often cited for roughness length and displacement height, respectively (Bonan 2002). Second, coupling with LPJ revealed an inappropriate scaling of leaf stomatal conductance to the canopy. In LSM1, leaf physiology is scaled to the canopy using sunlit and shaded leaves, which vary in photosynthesis and stomatal conductance. The LSM1 formulation of these processes for shaded leaves was found to be unrealistic, allowing for net carbon gain at high leaf area index. In LSM2, the canopy scaling is replaced by an assumption similar to that of the Simple Biosphere model version 2 (SiB2) whereby only sunlit leaves photosynthesize (Sellers et al. 1992, 1996). Third, values of maximum carboxylation at $25^{\circ} \mathrm{C}\left(V_{\max 25}\right)$, a key determinant of leaf photosynthesis and stomatal conductance, were increased from LSM1 values to maintain realistic canopy photosynthesis. These values of $V_{\max 25}$, roughness length, and displacement height are also used in CLM2 and are listed with other CLM2 parameter values (section 2c).

An additional feature of LSM2 is that soil texture (percent sand and clay) varies with depth according to the IGBP soil dataset (Global Soil Data Task 2000). This was motivated by a desire to include dust emissions as a component of the land model. Preliminary simulations with a dust emission parameterization found better entrainment of dust into the atmosphere in the Sahara Desert, a high dust source region, with the sandier top soil layers of the IGBP dataset rather than a uniform soil profile as in LSM1.

The surface dataset for LSM2 includes: the glacier, lake, wetland, and urban portions of the grid cell (vegetation occupies the remainder); the fractional cover in the vegetated portion of the grid cell of the four most abundant PFTs; monthly leaf and stem area index and canopy top and bottom heights for each PFT; soil color; and soil texture. These fields are aggregated to the CCM3 T42 grid from high-resolution surface datasets (Table 1). In contrast to LSM1, there is no irrigation of crops. This is because LSM1 recognizes irrigated crops as a biome, but LSM2 only recognizes a crop PFT.

Table 2 summarizes the differences between LSM1 and LSM2. The primary difference is related to surface datasets: the representation of subgrid land cover, vegetation structure, and soil texture. Biogeophysical parameterizations are the same except for canopy scaling and leaf physiology.

\section{c. CLM2}

In contrast to LSM2, which differs primarily from LSM1 in surface datasets, CLM2 uses the same surface datasets as LSM2 but differs from LSM2 in biogeophysical parameterizations. Many of the parameterizations are from the common land model (Zeng et al. 2002), reconciled with the goal of including the carbon cycle and vegetation dynamics (Table 3 ). Major model differences from LSM1 include the LSM2 changes, as well as 10 layers for soil temperature and soil water with explicit treatment of liquid water and ice; a multilayer snowpack with up to 5 layers depending on snow depth; a runoff parameterization based on the TOPMODEL concept (Beven and Kirkby 1979); new formulation of ground and vegetation fluxes; and vertical root profiles from Zeng (2001).

Several differences in biogeophysical parameterizations between LSM1 and CLM2 explain many of the differences in simulated climate when coupled to CCM3. Both models have the same maximum canopy water storage $(0.1 \mathrm{~mm}$ per unit leaf and stem area), but LSM1 restricts interception to $20 \%$ of precipitation while CLM2 intercepts more precipitation for leaf and stem area greater than about $0.5 \mathrm{~m}^{2} \mathrm{~m}^{-2}$ (Fig. 2). At leaf and stem area index greater than about $4.5 \mathrm{~m}^{2} \mathrm{~m}^{-2}$, CLM2 allows more than $90 \%$ of precipitation to be intercepted (if storage capacity is not exceeded).

In both models, dry soils restrict transpiration by re- 
TABLE 2. Differences between LSM1 and LSM2.

\begin{tabular}{|c|c|c|}
\hline Process/parameterization & LSM1 & LSM2 \\
\hline Land cover & $\begin{array}{l}\text { Biome approach. Biomes determine PFTs. } \\
\text { Glaciers are a biome, but lakes and wet- } \\
\text { lands are subgrid patches. }\end{array}$ & $\begin{array}{l}\text { Subgrid representation of glacier, lake, wet- } \\
\text { land, urban, and vegetation. Explicit repre- } \\
\text { sentation of PFTs. }\end{array}$ \\
\hline Vegetation structure & $\begin{array}{l}\text { Leaf area index, stem area index, roughness } \\
\text { length, displacement height, canopy top } \\
\text { and bottom heights, and root distribution } \\
\text { based on PFTs. }\end{array}$ & $\begin{array}{l}\text { Leaf area index, stem area index, and cano- } \\
\text { py heights in surface datasets. Roughness } \\
\text { length and displacement height depend on } \\
\text { canopy height. Root distribution depends } \\
\text { on PFTs. }\end{array}$ \\
\hline Soil texture & Sand and clay constant with depth. & Sand and clay vary with depth. \\
\hline Canopy scaling & $\begin{array}{l}\text { Sunlit and shaded leaves. Sunlit leaves re- } \\
\text { ceive direct beam and a portion of diffuse } \\
\text { radiation. Shaded leaves receive only dif- } \\
\text { fuse radiation. }\end{array}$ & $\begin{array}{l}\text { Sunlit and shaded leaves. Sunlit leaves re- } \\
\text { ceive all radiation. Shaded leaves dark. }\end{array}$ \\
\hline Leaf physiology & & $\begin{array}{l}\text { Altered } V_{\max 25} \text { to represent new canopy scal- } \\
\text { ing. }\end{array}$ \\
\hline
\end{tabular}

ducing photosynthesis and stomatal conductance. However, the relative influence of soil water varies greatly between the models (Fig. 3). In LSM1, soil water does not restrict photosynthesis and stomatal conductance until soil is near wilting point. The CLM2 parameterization causes greater reduction for a similar water content; hence, CLM2 has tighter control on transpiration by soil water.

Aerodynamic resistances to heat exchange from ground also differ between models. CLM2 uses a lower roughness length for bare ground than LSM1 and distinguishes between momentum and thermal roughness. The result is that CLM2 has a higher aerodynamic resistance to heat fluxes from bare ground (Fig. 4). Within canopy, aerodynamic processes also differ. CLM2 uses an aerodynamic resistance to heat exchange between the ground and canopy air that is greater than that of LSM1 (Fig. 4).

CLM2 differs from LSM1 in its representation of snow. CLM2 uses a multilayered snow. Heat and moisture transfer in the snowpack are based on temperature and water gradients between snow layers and on the physical properties of snow. LSM1 uses a single snow layer, blending the thermal properties of snow into the first soil layer and melting snow by solving the surface energy balance with a ground temperature of $0^{\circ} \mathrm{C}$. In addition, thermal conductivity and heat capacity in CLM2 vary with the density of snow but are constants in LSM1. Snow thermal conductivity in CLM2 is less than LSM1, especially at low bulk density and, hence, snow is a better insulator in CLM2. Offline simulations of LSM1 and CLM2 show CLM2 better simulates snow, especially during the melt season (Fig. 5).

Because CLM2 uses the same surface datasets as LSM2, it employs the same plant functional types. These plant types are defined in terms of leaf and stem optical properties (Table 4), plant morphology (Table 5), and photosynthetic parameters (Table 6).

\section{d. Observations}

Version 3.01 of the Willmott and Matsuura monthly terrestrial air temperature and precipitation climatology (Willmott and Matsuura 2000) was used to test the models. These datasets were created from the Global Historical Climatology Network (GHCN, ver. 2) and Legates and Willmott's (1990a,b) station records of monthly air temperature covering the period 1950-96. Station data were interpolated to a $0.5^{\circ}$ grid using a distance-weighting method, with climatologically aided interpolation (Willmott and Robeson 1995) and adjustment of temperature for elevation (Willmott and Matsuura 1995).

Observed monthly snow cover was obtained from the National Snow and Ice Data Center (1996a,b) Northern Hemisphere weekly climatological snow cover dataset for the period 1971-95. This climatology was derived from the National Oceanic and Atmospheric Administration National Environmental Satellite, Data, and Information Service (NOAA/NESDIS) weekly snow charts derived from manual interpretation of AVHRR, Geostationary Operational Environmental Satellite (GOES), and other visible-band satellite data, and then revised as in Robinson et al. (1993). The NOAA charts were digitized to an $89 \times 89$ grid and then interpolated to the final grid. Only grid cells at least $50 \%$ covered with snow were categorized as snow covered. Snow cover extent was defined as the area covered by at least $1-\mathrm{cm}$ snow depth for the NOAA data (Foster et al. 1996). This corresponds to a snow water equivalent threshold of $2.5 \mathrm{~mm}$ in the models (assuming a snow density of $250 \mathrm{~kg} \mathrm{~m}^{-3}$ ).

Observed runoff was obtained from the University of New Hampshire-Global Runoff Data Center (UNHGRDC) $0.5^{\circ}$ monthly climatological composite runoff fields of Fekete et al. (2000). These fields were generated by combining observed river discharge information with output from a climate-driven water balance model. This preserves the accuracy of the discharge fields while disaggregating the discharge spa- 
TABLE 3. Conceptual similarities and differences between LSM1 and CLM2.

\begin{tabular}{|c|c|c|}
\hline Process/Parameterization & LSM1 & CLM2 \\
\hline Land cover & $\begin{array}{l}28 \text { biomes provide } 2 \text { subgrid PFT patches. } \\
\text { Subgrid lake and wetland patches. Leaf } \\
\text { area index, stem area index, roughness } \\
\text { length, displacement height, canopy top } \\
\text { and bottom heights, and root distribution } \\
\text { based on PFTs. }\end{array}$ & $\begin{array}{l}\text { LSM2: subgrid glacier, lake, wetland, urban, } \\
\text { and vegetation. Explicit representation of } \\
\text { PFTs. Explicit leaf area index, stem area } \\
\text { index, and canopy heights in surface data- } \\
\text { sets. Roughness length and displacement } \\
\text { height depend on canopy height. Root dis- } \\
\text { tribution depends on PFTs using common } \\
\text { land model formulation. }\end{array}$ \\
\hline Vegetation & $\begin{array}{l}\text { One canopy layer for fluxes, but two leaves } \\
\text { (sunlit, shaded) for canopy integration of } \\
\text { stomatal conductance. }\end{array}$ & $\begin{array}{l}\text { Common land model: one canopy layer for } \\
\text { fluxes, but two leaves (sunlit, shaded) for } \\
\text { canopy integration of stomatal conduc- } \\
\text { tance. }\end{array}$ \\
\hline Snow & $\begin{array}{l}\text { One layer mass balance. Blended with top } \\
\text { soil layer for heat transfer. Snow covers } \\
\text { ground in relation to snow depth and bur- } \\
\text { ies vegetation vertically in relation to can- } \\
\text { opy bottom height. }\end{array}$ & $\begin{array}{l}\text { Common land model formulation of up to } \\
\text { five layers depending on snow depth. } \\
\text { LSM1 vertical burying of vegetation and } \\
\text { common land model fractional snow-cov- } \\
\text { ered ground. }\end{array}$ \\
\hline Soil & $\begin{array}{l}\text { Six layers to depth of } 6.3 \mathrm{~m} \text {. First layer } 10 \\
\mathrm{~cm} \text { thick. Thermal and hydraulic proper- } \\
\text { ties depend on sand and clay. Sand and } \\
\text { clay constant with depth. }\end{array}$ & $\begin{array}{l}\text { Common land model: ten layers to depth of } \\
3.43 \mathrm{~m} \text {. First layer } 1.75 \mathrm{~cm} \text { thick. Thermal } \\
\text { and hydraulic properties depend on sand } \\
\text { and clay. Sand and clay vary with depth } \\
\text { as in LSM2. }\end{array}$ \\
\hline Lake & Six layers to depth of $50 \mathrm{~m}$. & $\begin{array}{l}\text { Common land model: As in LSM1 but with } \\
10 \text { layers. }\end{array}$ \\
\hline \multicolumn{3}{|c|}{ Albedo } \\
\hline Snow & $\begin{array}{l}\text { Depends on zenith angle, soot content, and } \\
\text { grain radius. }\end{array}$ & $\begin{array}{l}\text { Common land model: BATS snow albedo } \\
\text { varying with snow age and zenith angle. }\end{array}$ \\
\hline Soil & $\begin{array}{l}\text { BATS color classes and soil water depen- } \\
\text { dence. Blended with snow. }\end{array}$ & $\begin{array}{l}\text { Common land model: BATS color classes } \\
\text { and soil water dependence. Blended with } \\
\text { snow. }\end{array}$ \\
\hline Vegetation & $\begin{array}{l}\text { Two-stream radiative transfer. PFT-dependent } \\
\text { leaf optical properties modified by inter- } \\
\text { cepted snow. Exposed leaf and stem area } \\
\text { above snow decreases as snow accumu- } \\
\text { lates above lower canopy height. }\end{array}$ & LSM1. \\
\hline \multicolumn{3}{|c|}{ Hydrology } \\
\hline Interception & $\begin{array}{l}\text { Maximum storage is } 0.1 \mathrm{~mm} \text { times leaf and } \\
\text { stem area. Interception either to storage } \\
\text { capacity or } 20 \% \text { of precipitation. Separate } \\
\text { regions receiving large-scale and convec- } \\
\text { tive precipitation. }\end{array}$ & $\begin{array}{l}\text { Common land model: Interception either to } \\
\text { storage capacity (same as LSM1) or some } \\
\text { fraction of precipitation. Fraction of pre- } \\
\text { cipitation intercepted increases with leaf } \\
\text { and stem area. }\end{array}$ \\
\hline Surface runoff & $\begin{array}{l}\text { Runoff from saturated and unsaturated } \\
\text { zones. Exponential spatial distribution of } \\
\text { soil water determines saturated area. Sepa- } \\
\text { rate regions receiving large-scale and con- } \\
\text { vective precipitation. Precipitation has ex- } \\
\text { ponential distribution in each region. }\end{array}$ & $\begin{array}{l}\text { Common land model: Saturated and unsatu- } \\
\text { rated zones using TOPMODEL-like ap- } \\
\text { proach. Exponential decrease in saturated } \\
\text { hydraulic conductivity determines water } \\
\text { table depth and saturated area. }\end{array}$ \\
\hline Base flow (drainage) & $\begin{array}{l}\text { Depends on hydraulic conductivity of bot- } \\
\text { tom soil layer regardless of temperature. }\end{array}$ & $\begin{array}{l}\text { Common land model: ice-free soil only. De- } \\
\text { pends on hydraulic conductivity (unsatu- } \\
\text { rated zone) or base rate and water table } \\
\text { depth (saturated zone). }\end{array}$ \\
\hline Snow & One layer mass balance. & $\begin{array}{l}\text { Common land model: up to five layers de- } \\
\text { pending on snow depth. Compaction al- } \\
\text { lowed. Ice and liquid water. Heat and wa- } \\
\text { ter flow between layers. }\end{array}$ \\
\hline Soil water & $\begin{array}{l}\text { Darcy's law for vertical fluxes. Water re- } \\
\text { moved by evaporation from top layer, } \\
\text { transpiration from each layer in proportion } \\
\text { to root abundance, and drainage from bot- } \\
\text { tom layer. No distinction between ice and } \\
\text { water. }\end{array}$ & $\begin{array}{l}\text { Common land model: Darcy's law for verti- } \\
\text { cal fluxes. Water removed by evaporation } \\
\text { from top layer, transpiration from each } \\
\text { layer in proportion to root abundance, and } \\
\text { drainage from deep layers. Separate ice } \\
\text { and water. }\end{array}$ \\
\hline
\end{tabular}


TABLE 3. (Continued)

\begin{tabular}{lcc}
\hline \hline Process/Parameterization & LSM1 & CLM2 \\
\hline
\end{tabular}

Ground fluxes

Turbulent fluxes

Soil moisture limitation to evaporation

Ground temperature

Soil temperature

Leaf temperature and turbulent fluxes

Leaf boundary layer resistance

Leaf stomatal resistance

Canopy resistance

Soil-to-air exchange

Above-canopy exchange
Monin-Obukhov similarity theory.

Surface resistance that depends on soil water.

Newton-Raphson iteration of surface energy budget. Soil heat flux used to update soil temperatures.

Crank-Nicholson formulation of 1D heat flow and energy conservation. Apparent heat capacity accounts for phase change. Snow blended into first soil layer. Explicit coupling with ground fluxes.

Vegetation fluxes

Sensible heat from foliage and ground. Latent heat from ground, intercepted water, and transpiration. Newton-Raphson iteration of energy budget.

Depends on leaf dimension and wind speed. Wind speed integrated through canopy assuming exponential decline in wind.

Stomatal resistance depends on photosynthesis in relation to light, temperature, $\mathrm{CO}_{2}$. vapor pressure, foliage nitrogen, and soil water. Soil water affects photosynthesis by altering $V_{\max 25}$. Soil water factor is a linear function of soil water scaled to 1 at some optimal value and 0 when dry.

Sunlit and shaded leaves used to integrate leaf resistance to canopy (Table 2).

Within canopy aerodynamic resistance based on friction velocity and exponential profile of eddy diffusivity for heat.

Monin-Obukhov similarity theory.
Common land model: Monin-Obukhov similarity theory but different flux-gradient relations. Lower aerodynamic roughness for momentum than LSM1. Separate thermal roughness for heat and water vapor.

Common land model: soil relative humidity modifies ground specific humidity.

Common land model: coupled to snow-soil temperature algorithm. Top layer heat capacity modified by adjusting thickness to obtain ground skin temperature.

Common land model: Crank-Nicholson formulation of $1 \mathrm{D}$ heat flow and energy conservation through snow-soil column. Frozen and liquid water. Phase change by setting temperature to freezing, accounting for energy change. Implicit coupling with ground fluxes.

Common land model: BATS formulation of leaf temperature and fluxes. Sensible heat from foliage and ground. Latent heat from ground, intercepted water, and transpiration. Newton-Raphson iteration of energy budget.

Common land model: BATS formulation. Depends on leaf dimension and friction velocity.

LSM1, but common land model formulation of soil water limitation. Soil water factor is nonlinear function of soil water based on matric potential and root resistance.

\section{LSM2 (Table 2).}

Common land model: BATS formulation based on friction velocity times a constant transfer coefficient.

Common land model: Monin-Obukhov similarity theory, but different flux-gradient relations. tially and temporally to enable comparisons with climate model output.

\section{Results and discussion}

\section{a. Surface air temperature}

Bonan (1998) describes the surface climatology of CCM3 with LSM1. The Tropics between $15^{\circ} \mathrm{S}$ and $15^{\circ} \mathrm{N}$ and the midlatitudes of the United States and Europe are generally well simulated throughout the year with temperatures for the most part within $\pm 2{ }^{\circ} \mathrm{C}$ of observations. The transition seasons (spring, autumn) are better simulated than winter or summer. A prominent winter bias is that surface air temperature is several degrees warmer than observations in a broad band of North America extending from central Canada northwest to Alaska and in Asia extending from the Caspian Sea to eastern Siberia. This warm bias is present in versions of CCM3 without LSM1. A prominent summer bias is that much of the Northern Hemisphere land is several degrees too cold. Prominent year-round temperature biases include the Andes region of South America, India, and the Tibetan Plateau, which are several degrees too cold throughout the year. The Sahara Desert and Arabian Peninsula are also several degrees too cold throughout the year, possibly due in part to the assumed high surface albedos.

CLM2 generally warms surface air temperature in all seasons compared to LSM1 (Fig. 6). Only three regions 


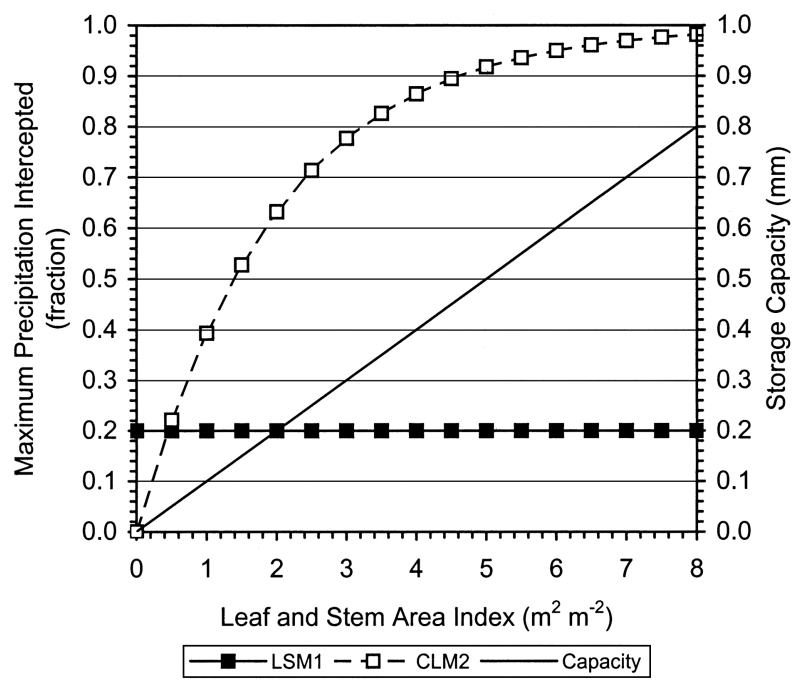

FIG. 2. Interception of water in LSM1 and CLM2. Both models intercept a fraction of the incoming precipitation up to a maximum storage capacity. The left axis shows the maximum fraction of precipitation intercepted, which differs between LSM1 and CLM2. The right axis shows the storage capacity, which is the same in both models.

are cooler: North Africa year-round; northern regions of North America and Eurasia in winter; and Greenland year-round. The warming introduced by CLM2 reduces or eliminates many cold biases found in LSM1 (Fig. 7). In particular, the prominent Northern Hemisphere summer cold bias of LSM1 is virtually eliminated and, in fact, a warm bias has been introduced, especially in the United States. Another prominent difference is that the year-round cold bias over the Tibetan Plateau has been reduced (Fig. 7). This is due in part to the warmer climate of CLM2 (Fig. 6), but also to cooler temperatures in the new observation dataset. The Tropics between $15^{\circ} \mathrm{S}$ and $15^{\circ} \mathrm{N}$ are well simulated throughout the year with temperatures for the most part within $\pm 2^{\circ} \mathrm{C}$ of the observations. The Amazon region of South America is an exception. Here, temperatures are too warm throughout the year, with largest bias in the dry season. Several poor aspects of the LSM1 simulations noted in Bonan (1998) remain. In particular, the Alaskan and Asian winter warm biases still occur. The Sahara Desert and Arabian Peninsula region is still several degrees too cold throughout the year, as is the Andes region of South America.

These temperature differences between models and biases with observations are evident in regional analyses of monthly surface air temperature. Temperatures in spring, summer, and autumn are well simulated in arctic and boreal latitudes, with the summer warming of CLM2 improving the simulation compared to LSM1 (Fig. 8). The winter warm bias of both models is evident in Alaska and northwest Canada, western Siberia, and eastern Siberia. The summer warming of CLM2 introduces a warm bias of a few degrees in midlatitudes compared to LSM1 (Fig. 9). Other times of the year are generally well sim-

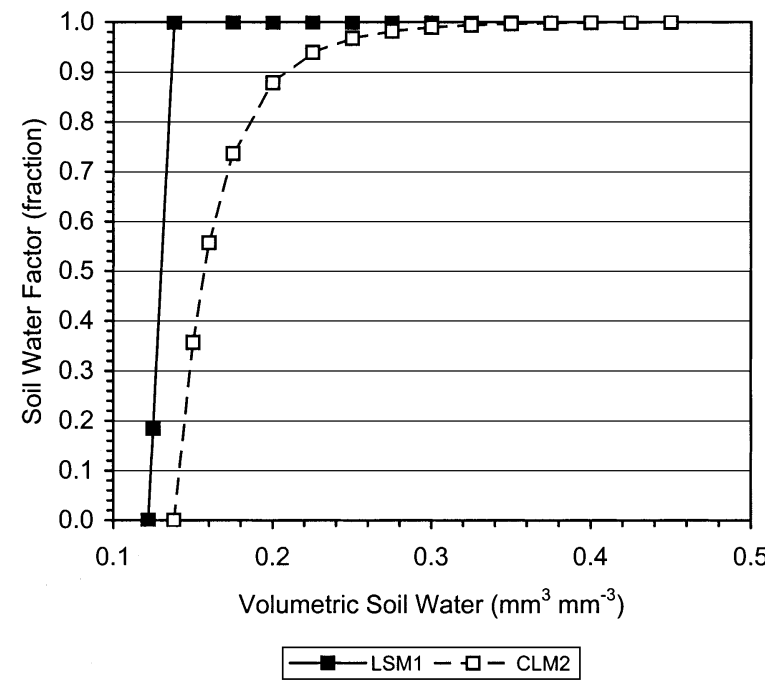

FIG. 3. Soil water factor in LSM1 and CLM2 in relation to soil water content for a loamy soil. This dimensionless factor reduces photosynthesis, stomatal conductance, and transpiration as the soil dries.

ulated compared to observations. Results in the Tropics are mixed (Fig. 10). CLM2 greatly improves simulated temperature in India. A small warm bias has been introduced in Central America. In central Africa, the warmer CLM2 temperatures are consistent with observations during the first half of the year and warmer than observations in the second half. Air temperatures are consistently warmer than observations throughout the year in the Amazon. In the Sahara Desert, southern South America, southern Africa, and Australia, CLM2 is consistently warmer than LSM1 throughout the year and generally reduces temperature biases seen in LSM1 (Fig. 11).

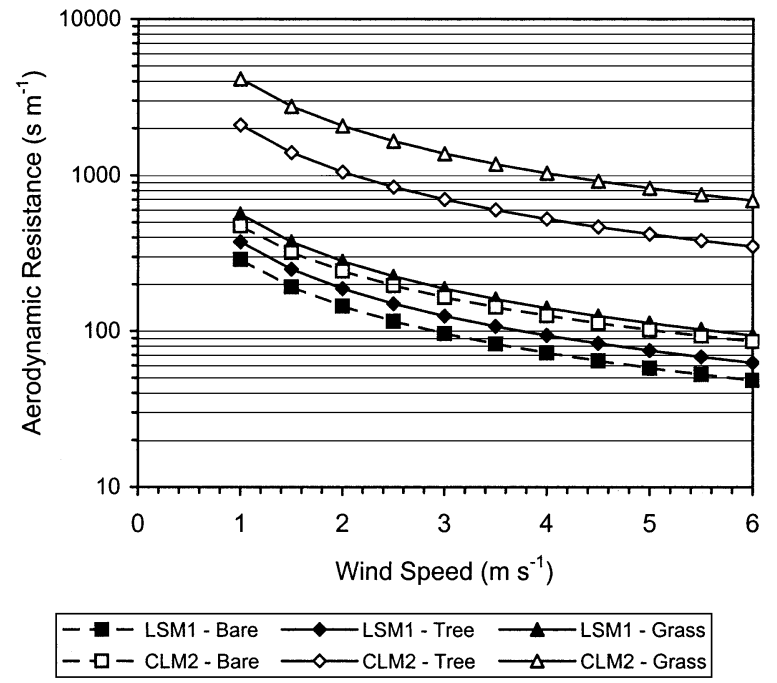

FIG. 4. Bare ground and within canopy aerodynamic resistances to heat and water in relation to wind speed for LSM1 and CLM2. Resistances use an atmospheric height of $45 \mathrm{~m}$ and neutral atmospheric conditions. Within canopy resistances are shown for tree and grass. 
VALDAI Daily Snow Water Equivalent
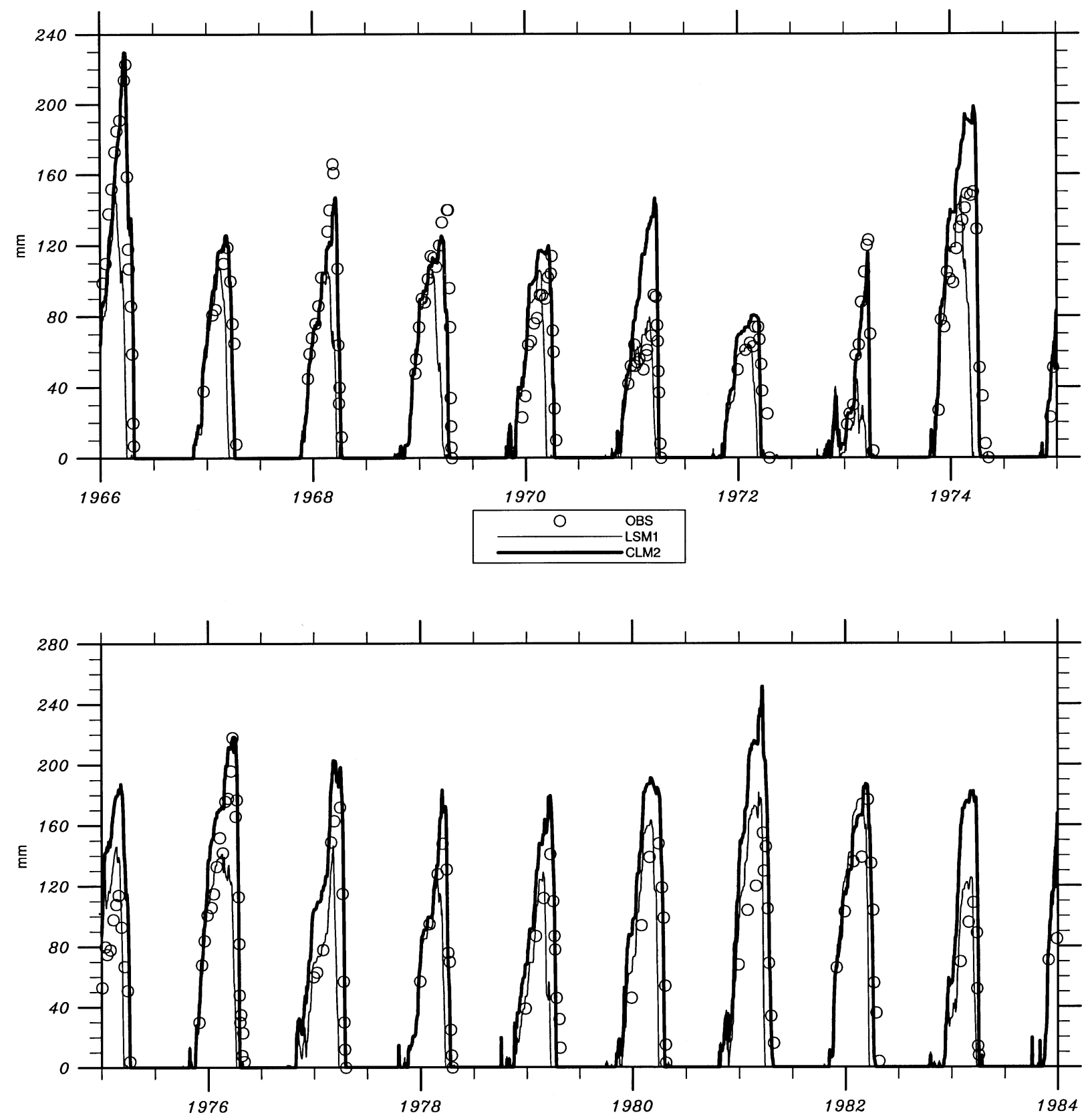

FIG. 5. Daily snow water equivalent simulated by LSM1 and CLM2 when forced with 18 yr (1966-83) of observed atmospheric data for a grassland catchment at the Valdai water balance research station (Vinnikov et al. 1996; Schlosser et al. 1997). The site is assumed to be $90 \% \mathrm{C}_{3}$ grassland and 10\% bare soil. The models were initialized repeating the first year of forcing until equilibrium (Yang et al. 1995). The observations are the daily average from up to 44 sites throughout the catchment (Schlosser et al. 1998).

Many of the temperature differences between CLM2 and LSM1 can be attributed to their different parameterization of biogeophysical processes rather than to different surface datasets. Comparison of CLM2 and LSM2, which use the same surface datasets but different biogeophysical parameterizations, show general patterns of winter cooling in northern regions of the Northern Hemisphere and year-round warming elsewhere
(Fig. 12). This accounts for much of the temperature difference seen in the comparison of CLM2 and LSM1 (Fig. 6). Indeed, differences in surface air temperature between LSM2 and LSM1 (Fig. 13) are generally smaller than those of CLM2 and LSM2 (Fig. 12). However, the changes associated with LSM2 negatively impact northern Africa year-round and northern Asia in winter. LSM2 cools surface air temperature in northern Af- 
TABLE 4. Optical properties for each plant functional type. Leaf angle refers to the departure of leaf angles from a random distribution with values of 1 for horizontal leaves, 0 for random leaves, and -1 for vertical leaves. Reflectance and transmittance are for visible (VIS) and near-infrared (NIR) wavebands; NET indicates needleleaf evergreen tree; NDT, needleleaf deciduous tree; BET, broadleaf evergreen tree; BDT, broadleaf deciduous tree; BES, broadleaf evergreen shrub; BDS, broadleaf deciduous shrub. Two types of crops are allowed to account for the different physiology of crops, but currently only one type is specified in the surface datasets.

\begin{tabular}{|c|c|c|c|c|c|c|c|c|c|}
\hline \multirow{2}{*}{$\begin{array}{l}\text { Plant functional } \\
\text { type }\end{array}$} & \multirow[b]{2}{*}{ Leaf angle } & \multicolumn{2}{|c|}{ Leaf reflectance } & \multicolumn{2}{|c|}{ Stem reflectance } & \multicolumn{2}{|c|}{ Leaf transmittance } & \multicolumn{2}{|c|}{ Stem transmittance } \\
\hline & & VIS & NIR & VIS & NIR & VIS & NIR & VIS & NIR \\
\hline NET temperate & 0.01 & 0.07 & 0.35 & 0.16 & 0.39 & 0.05 & 0.10 & 0.001 & 0.001 \\
\hline NET boreal & 0.01 & 0.07 & 0.35 & 0.16 & 0.39 & 0.05 & 0.10 & 0.001 & 0.001 \\
\hline NDT boreal & 0.01 & 0.07 & 0.35 & 0.16 & 0.39 & 0.05 & 0.10 & 0.001 & 0.001 \\
\hline BET tropical & 0.10 & 0.10 & 0.45 & 0.16 & 0.39 & 0.05 & 0.25 & 0.001 & 0.001 \\
\hline BET temperate & 0.10 & 0.10 & 0.45 & 0.16 & 0.39 & 0.05 & 0.25 & 0.001 & 0.001 \\
\hline BDT tropical & 0.01 & 0.10 & 0.45 & 0.16 & 0.39 & 0.05 & 0.25 & 0.001 & 0.001 \\
\hline BDT temperate & 0.25 & 0.10 & 0.45 & 0.16 & 0.39 & 0.05 & 0.25 & 0.001 & 0.001 \\
\hline BDT boreal & 0.25 & 0.10 & 0.45 & 0.16 & 0.39 & 0.05 & 0.25 & 0.001 & 0.001 \\
\hline BES temperate & 0.01 & 0.07 & 0.35 & 0.16 & 0.39 & 0.05 & 0.10 & 0.001 & 0.001 \\
\hline BDS temperate & 0.25 & 0.10 & 0.45 & 0.16 & 0.39 & 0.05 & 0.25 & 0.001 & 0.001 \\
\hline BDS boreal & 0.25 & 0.10 & 0.45 & 0.16 & 0.39 & 0.05 & 0.25 & 0.001 & 0.001 \\
\hline $\mathrm{C}_{3}$ grass arctic & -0.30 & 0.11 & 0.58 & 0.36 & 0.58 & 0.07 & 0.25 & 0.220 & 0.380 \\
\hline $\mathrm{C}_{3}$ grass & -0.30 & 0.11 & 0.58 & 0.36 & 0.58 & 0.07 & 0.25 & 0.220 & 0.380 \\
\hline $\mathrm{C}_{4}$ grass & -0.30 & 0.11 & 0.58 & 0.36 & 0.58 & 0.07 & 0.25 & 0.220 & 0.380 \\
\hline Crop1 & -0.30 & 0.11 & 0.58 & 0.36 & 0.58 & 0.07 & 0.25 & 0.220 & 0.380 \\
\hline Crop2 & - & - & - & - & - & - & - & - & - \\
\hline
\end{tabular}

rica compared to LSM1 (Fig. 13). This is due to increased sand content that creates a drier soil and increases surface albedo. This is seen in offline simulations of LSM2 that used either the LSM1 soil texture or the new IGBP soil texture. These simulations were forced with 3-h atmospheric data for the period from 1979 to 1995 (Bonan et al. 2002). With an increase in sand content, the soil dries, absorbed solar radiation decreases, and the ground surface cools (data not shown). The cooling produced by LSM2 in this region suggests that the cooler climate of CLM2 compared to LSM1 (Fig. 6) and the cold bias of CLM2 (Fig. 7) arise in part from the changed soil texture dataset between LSM1 and CLM2.

CLM2 biogeophysics cools much of the northern por- tions of the Northern Hemisphere in winter (Fig. 12). In northern Eurasia, the change from the blended snowsoil representation of snow in LSM1 to the multilayer snow of CLM2 likely contributes to the cooling. Indeed, this is seen in less heat loss from the soil in CLM2 compared to LSM1 (Table 7). Similar processes contribute to the cooling over North America (Table 7). Here, however, the cooling with CLM2 is augmented by higher surface albedo and more reflected solar radiation, which is one reason why the cooling is greater in North America than in Eurasia.

This winter cooling is desirable because it helps reduce a warm temperature bias in LSM1. Indeed, the warm bias in Canada is substantially reduced compared to the LSM1 warm bias reported by Bonan (1998). How-

TABLE 5. Morphology for each plant functional type. Roughness length and displacement height are in proportion to canopy top height. Root distribution at depth $z(\mathrm{~m})$ is $f(z)=1-0.5[\exp (-a z)+\exp (-b z)]$.

\begin{tabular}{|c|c|c|c|c|c|}
\hline \multirow[b]{2}{*}{ Plant functional type } & \multirow[b]{2}{*}{ Leaf dimension (m) } & \multirow[b]{2}{*}{ Roughness length } & \multirow{2}{*}{$\begin{array}{l}\text { Displacement } \\
\text { height }\end{array}$} & \multicolumn{2}{|c|}{ Root distribution } \\
\hline & & & & $a$ & $b$ \\
\hline NET temperate & 0.04 & 0.055 & 0.67 & 7.0 & 2.0 \\
\hline NET boreal & 0.04 & 0.055 & 0.67 & 7.0 & 2.0 \\
\hline NDT boreal & 0.04 & 0.055 & 0.67 & 7.0 & 2.0 \\
\hline BET tropical & 0.04 & 0.075 & 0.67 & 7.0 & 1.0 \\
\hline BET temperate & 0.04 & 0.075 & 0.67 & 7.0 & 1.0 \\
\hline BDT tropical & 0.04 & 0.055 & 0.67 & 6.0 & 2.0 \\
\hline BDT temperate & 0.04 & 0.055 & 0.67 & 6.0 & 2.0 \\
\hline BDT boreal & 0.04 & 0.055 & 0.67 & 6.0 & 2.0 \\
\hline BES temperate & 0.04 & 0.120 & 0.68 & 7.0 & 1.5 \\
\hline BDS temperate & 0.04 & 0.120 & 0.68 & 7.0 & 1.5 \\
\hline BDS boreal & 0.04 & 0.120 & 0.68 & 7.0 & 1.5 \\
\hline $\mathrm{C}_{3}$ grass arctic & 0.04 & 0.120 & 0.68 & 11.0 & 2.0 \\
\hline $\mathrm{C}_{3}$ grass & 0.04 & 0.120 & 0.68 & 11.0 & 2.0 \\
\hline $\mathrm{C}_{4}$ grass & 0.04 & 0.120 & 0.68 & 11.0 & 2.0 \\
\hline Crop1 & 0.04 & 0.120 & 0.68 & 6.0 & 3.0 \\
\hline Crop2 & - & - & - & - & - \\
\hline
\end{tabular}


TABLE 6. Photosynthetic parameters for each plant functional type. Path, photosynthetic pathway; $V_{\max 25}$, maximum carboxylation at $25^{\circ} \mathrm{C}\left[\mu \mathrm{mol}\left(\mathrm{CO}_{2}\right) \mathrm{m}^{-2} \mathrm{~s}^{-1}\right] ; \alpha$, quantum efficiency $\left[\mu \mathrm{mol}\left(\mathrm{CO}_{2}\right)\right.$ $\left.\mu \mathrm{mol}(\text { photon })^{-1}\right] ; m$, slope of conductance-photosynthesis relationship.

\begin{tabular}{lcccc}
\hline $\begin{array}{c}\text { Plant functional } \\
\text { type }\end{array}$ & Path & $V_{\max 25}$ & $\alpha$ & $m$ \\
\hline NET temperate & $\mathrm{C}_{3}$ & 51 & 0.06 & 6 \\
NET boreal & $\mathrm{C}_{3}$ & 43 & 0.06 & 6 \\
NDT boreal & $\mathrm{C}_{3}$ & 43 & 0.06 & 6 \\
BET tropical & $\mathrm{C}_{3}$ & 75 & 0.06 & 9 \\
BET temperate & $\mathrm{C}_{3}$ & 69 & 0.06 & 9 \\
BDT tropical & $\mathrm{C}_{3}$ & 40 & 0.06 & 9 \\
BDT temperate & $\mathrm{C}_{3}$ & 51 & 0.06 & 9 \\
BDT boreal & $\mathrm{C}_{3}$ & 51 & 0.06 & 9 \\
BES temperate & $\mathrm{C}_{3}$ & 17 & 0.06 & 9 \\
BDS temperate & $\mathrm{C}_{3}$ & 17 & 0.06 & 9 \\
BDS boreal & $\mathrm{C}_{3}$ & 33 & 0.06 & 9 \\
$\mathrm{C}_{3}$ grass arctic & $\mathrm{C}_{3}$ & 43 & 0.06 & 9 \\
C grass & $\mathrm{C}_{3}$ & 43 & 0.06 & 9 \\
C grass & $\mathrm{C}_{4}$ & 24 & 0.04 & 5 \\
Crop1 & $\mathrm{C}_{3}$ & 50 & 0.06 & 9 \\
Crop2 & - & - & - & - \\
\hline
\end{tabular}

ever, the cooling in Eurasia due to biogeophysical parameterizations is partially offset by the change in surface datasets from LSM1 to LSM2 (Fig. 13). In this region, winter surface air temperature warms by a few degrees. Uncoupled simulations of LSM2 show that this warming is attributable to the IGBP soil texture dataset (data not shown). In the region of interest, clay content increases and sand content decreases. Soil moisture increases because of the higher matric potential and poorer drainage of clay soils. With wetter soil, the volumetric latent heat of fusion of soil increases, more energy is released in freezing soil, and the soil is warmer.

The cooling produced by CLM2 over Greenland contrasts with the warming over Antarctica (Fig. 6). The different climatic impacts of CLM2 on Greenland and Antarctica arise because of differences in snow albedo compared to LSM1. CLM2 has lower surface albedo over Antarctica, but higher surface albedo over Greenland. Differences in snow albedo between the two models arise due to differences in how soot, snow age, and meltwater affect snow albedo.

\section{b. Precipitation}

Precipitation is for the most part reduced in CLM2 compared to LSM1 (Fig. 14). Only tropical South America and Africa have a consistent year-round increase in precipitation, with the geographic location of this increase changing seasonally in relation to the seasonal

\section{CLM2 - LSM1 Surface Air Temperature Difference}
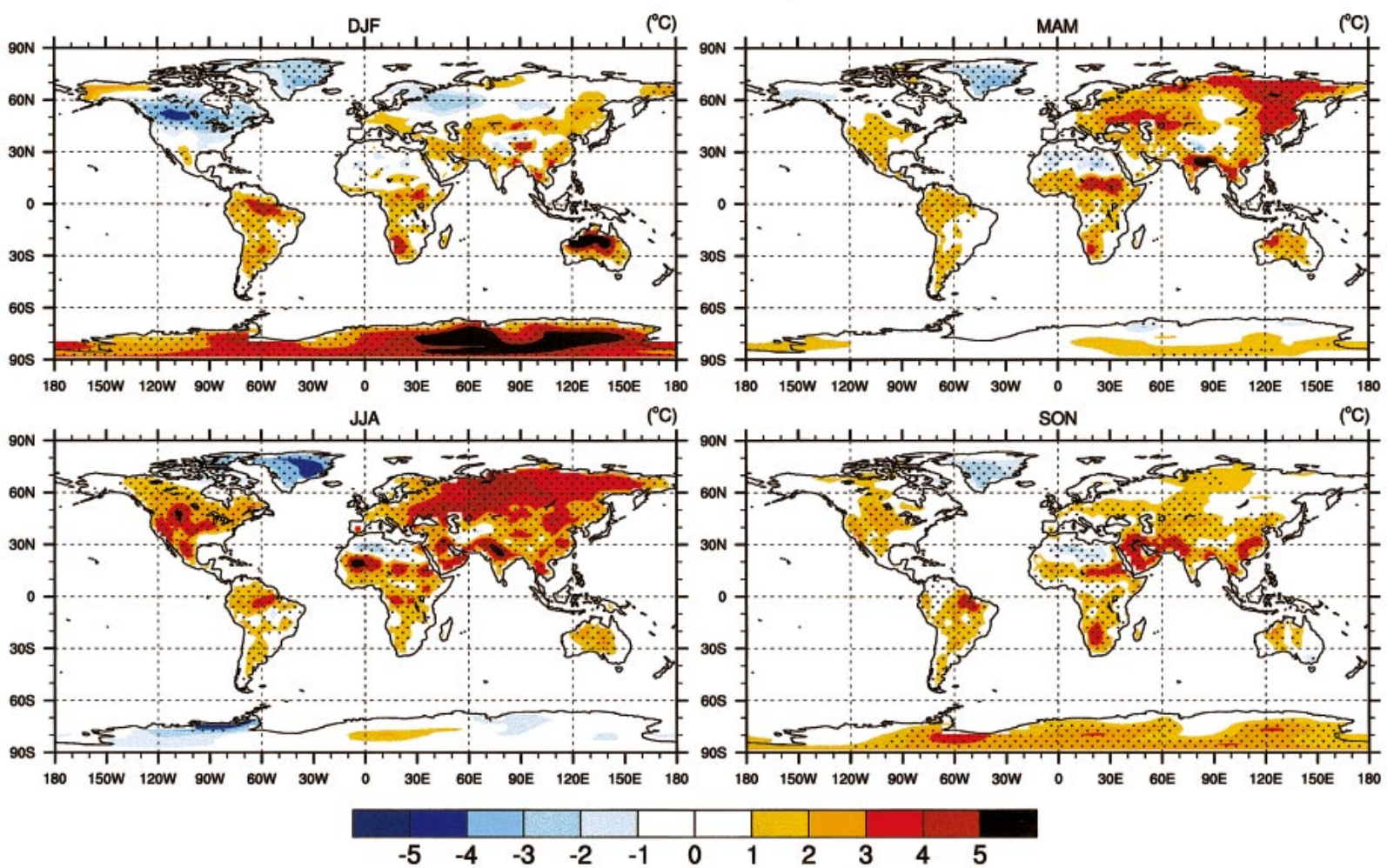

FIG. 6. Surface ( $2 \mathrm{~m}$ ) air temperature difference between CLM2 and LSM1 (CLM2 - LSM1) for the four seasons (Dec-Feb, Mar-May, Jun-Aug, and Sep-Nov). Stippling shows regions where the difference is statistically significant based on a $t$ test $(p<0.05)$. Surface air temperature is averaged over all model time steps. 


\section{CLM2 - Willmott/Matsuura Surface Air Temperature Difference}

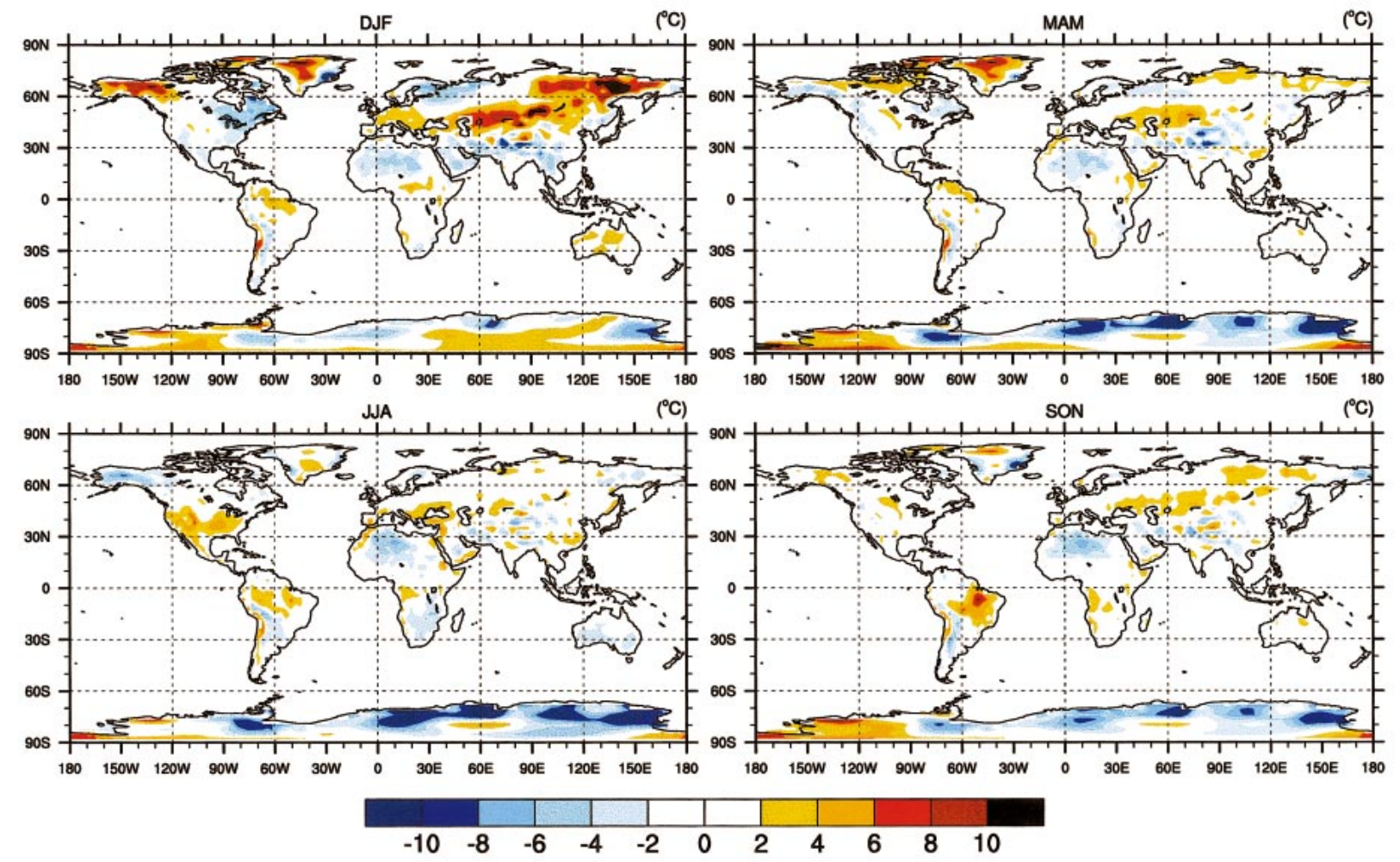

FIG. 7. CLM2 surface ( $2 \mathrm{~m}$ ) air temperature bias compared to the Willmott and Matsuura (2000) observations for the four seasons. Surface air temperature from the model is the average over all model time steps not the average of daily maximum and minimum temperatures.

migration of the intertropical convergence zone. Increased precipitation in these regions accentuates wet biases in the model (Fig. 15). Regional analyses of monthly precipitation also show the general reduction in precipitation (Figs. 8-11). CLM2 reduces annual precipitation by $4 \%-11 \%$ in arctic and boreal latitudes, $11 \%-17 \%$ in midlatitudes, $5 \%-21 \%$ in the Tropics, and $6 \%-35 \%$ in arid regions compared to LSM1 (Table 8). Annual precipitation over land is reduced from $2.35 \mathrm{~mm}$ day $^{-1}$ in LSM1 to $2.14 \mathrm{~mm} \mathrm{day}^{-1}$ in CLM2, compared to $2.01 \mathrm{~mm} \mathrm{day}^{-1}$ for the observations.

\section{c. Snow cover}

In North America, CLM2 has higher snow cover than LSM1, especially during the melt season, and better reproduces observations (Fig. 16). This is also seen in simulations for an individual watershed, where CLM2 better represents the melt season compared to LSM1 (Fig. 5) and likely represents improvements in snow albedo and heat transfer. Less snow cover in LSM1 during the melt season is also seen in Eurasia, although here both models compare favorably with observations (Fig. 16).

\section{d. Surface energy fluxes}

The global surface energy budget over land shows reduced latent heat flux relative to sensible heat flux for CLM2 (Table 9). This is likely the cause of the warm season warming in CLM2. Indeed, Bonan (1998) attributed the large Northern Hemisphere summer cold bias of LSM1 to high latent heat flux. The reduction in latent heat arises from a decrease in transpiration, large increase in evaporation of intercepted water, and large reduction in ground evaporation. Reduced latent heat, in part due to drier soils as a result of high interception (Fig. 2) but also due to tighter soil water control on transpiration (Fig. 3), likely contributes to the reduced rainfall.

Regional energy fluxes highlight the reduction in latent heat and increase in sensible heat for CLM2 compared to LSM1. This is illustrated for arctic and boreal latitudes by east Siberia (Fig. 17). Here, the change in transpiration is negligible compared to the large summer increase in canopy evaporation and decrease in ground evaporation. With a warmer surface, sensible heat and net longwave emission to the atmosphere increase. Similar changes occur in midlatitudes and tropical latitudes with the exception that transpiration is substantially re- 
Alaska + Northwest Canada 50-70N,170-100W
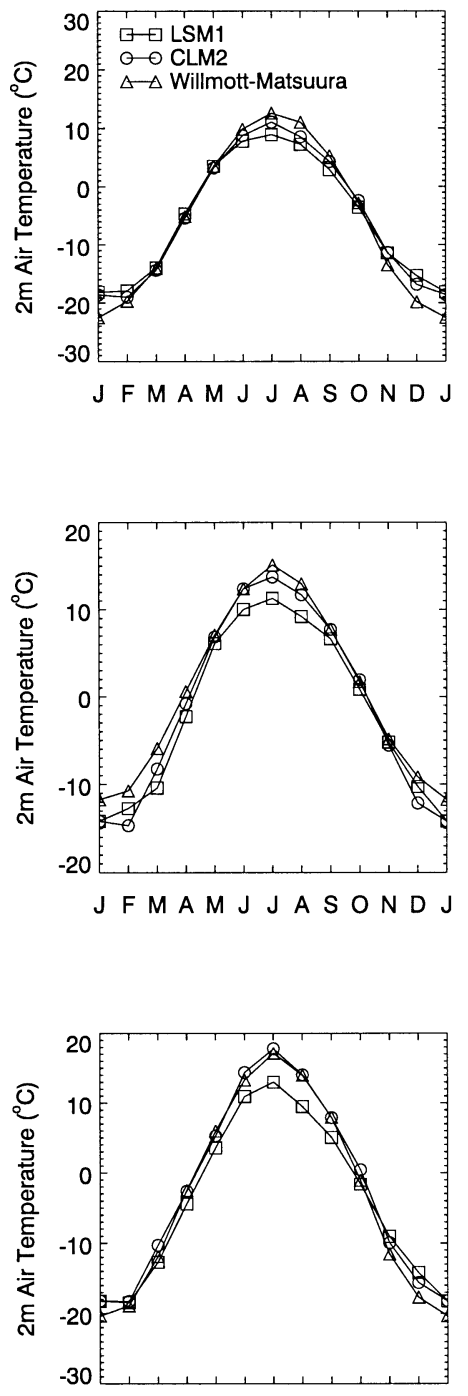

JFMAM J JASOND J

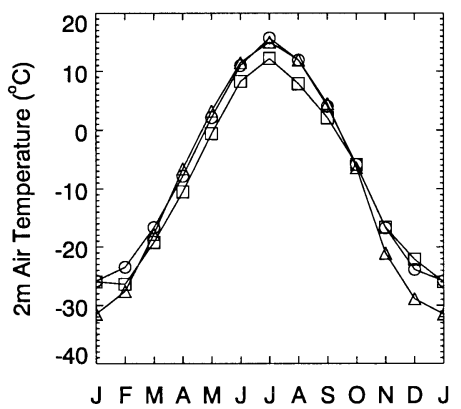

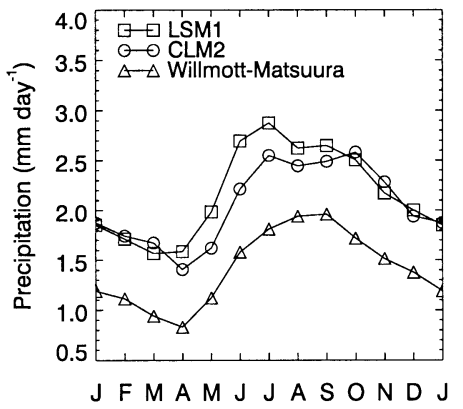

Northern Europe 55-70N,5-60E

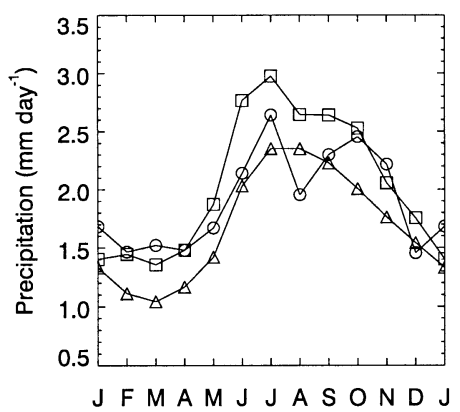

West Siberia 50-70N,60-90E

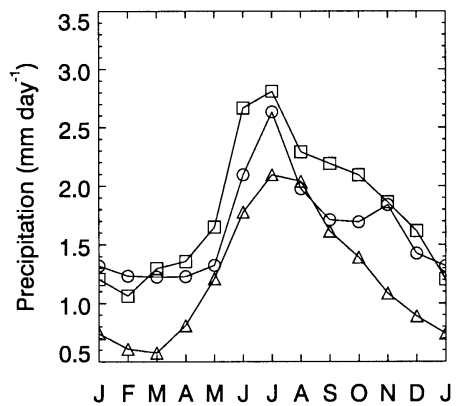

East Siberia $50-70 \mathrm{~N}, 90-140 \mathrm{E}$

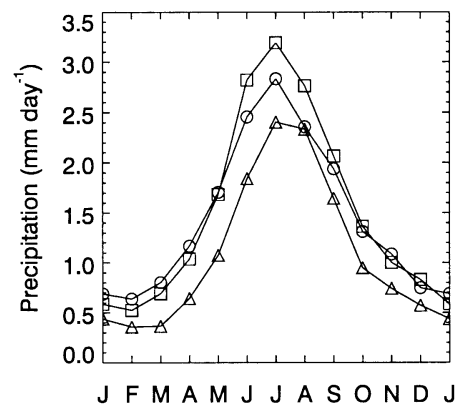

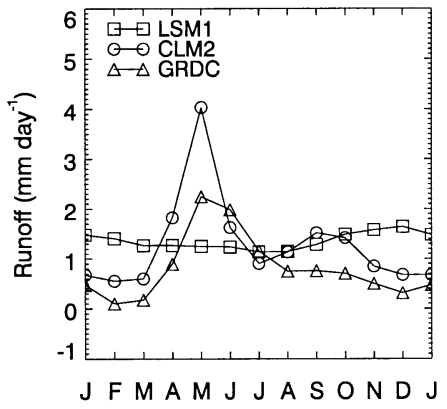
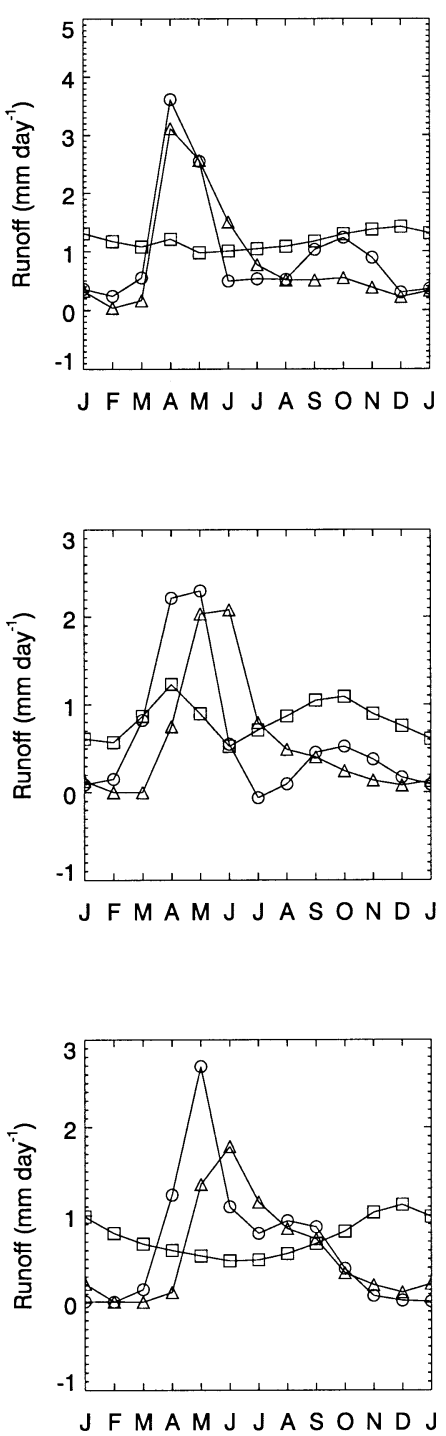

FIG. 8. Regionally averaged monthly surface $(2 \mathrm{~m})$ air temperature, precipitation, and runoff for LSM1, CLM2, and observations in arctic and boreal latitudes. Data are spatially averaged for land points. 
Western U.S. $30-50 \mathrm{~N}, 130-110 \mathrm{~W}$

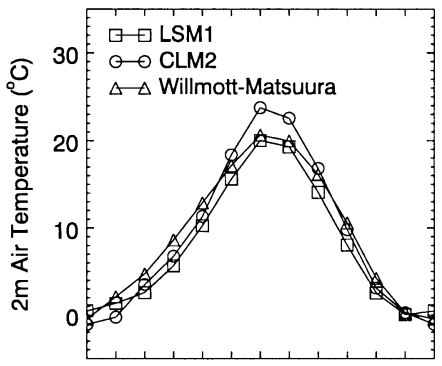

JFMAMJ JASONDJ
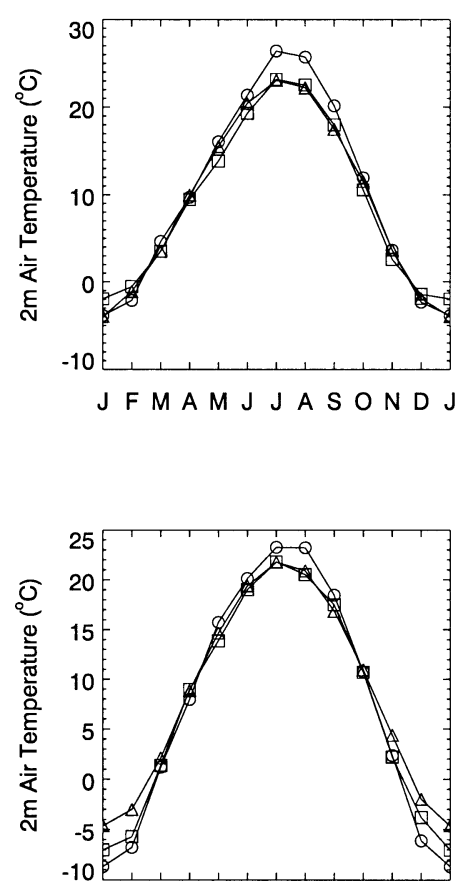

JFMAMJJASONDJ

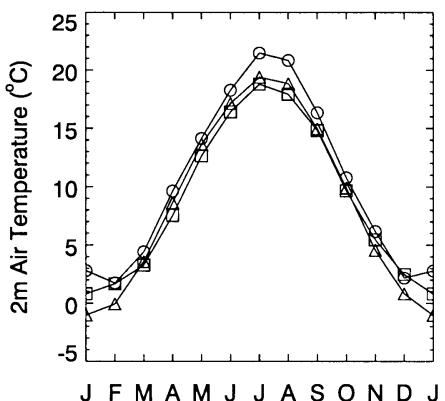

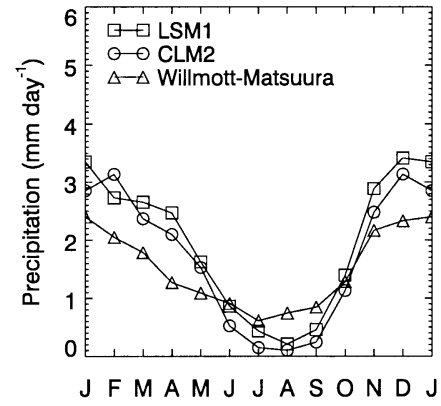

Central U.S. $30-50 \mathrm{~N}, 110-90 \mathrm{~W}$

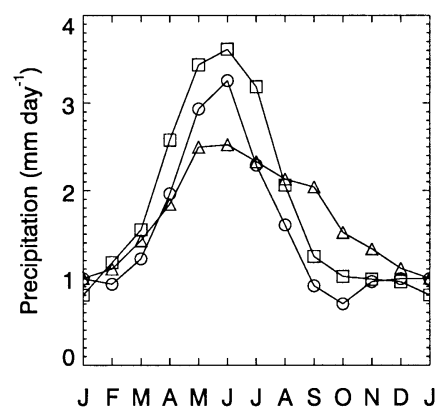

Eastern U.S. 30-50N,90-70W

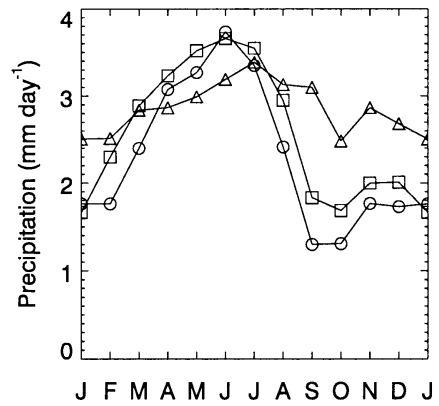

Central Europe 40-55N,10W-40E

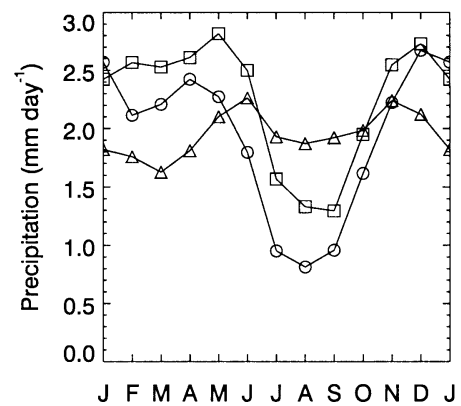

FIG. 9. As in Fig. 8 but for midlatitudes.
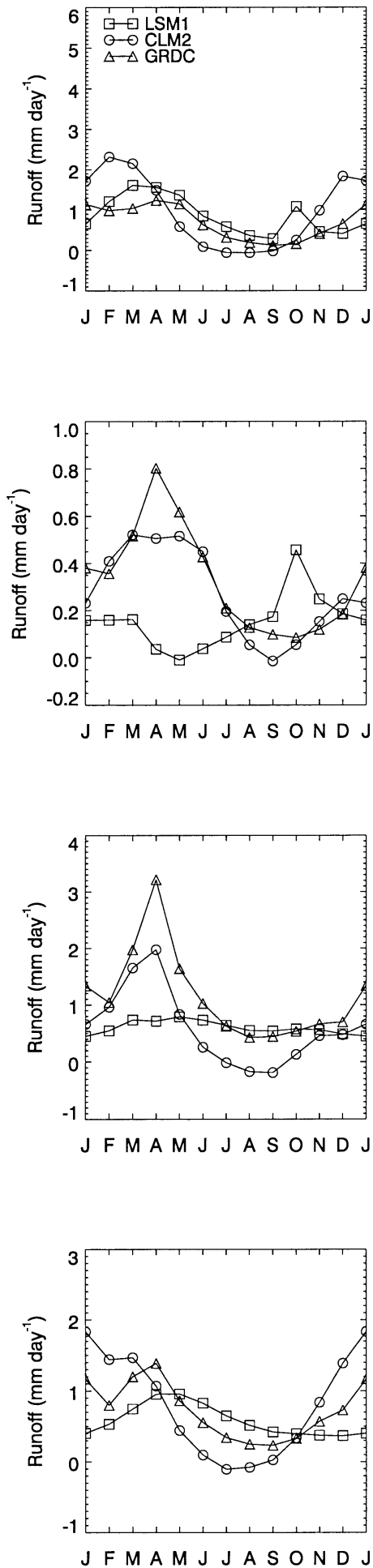
Central America 10-25N,110-80W
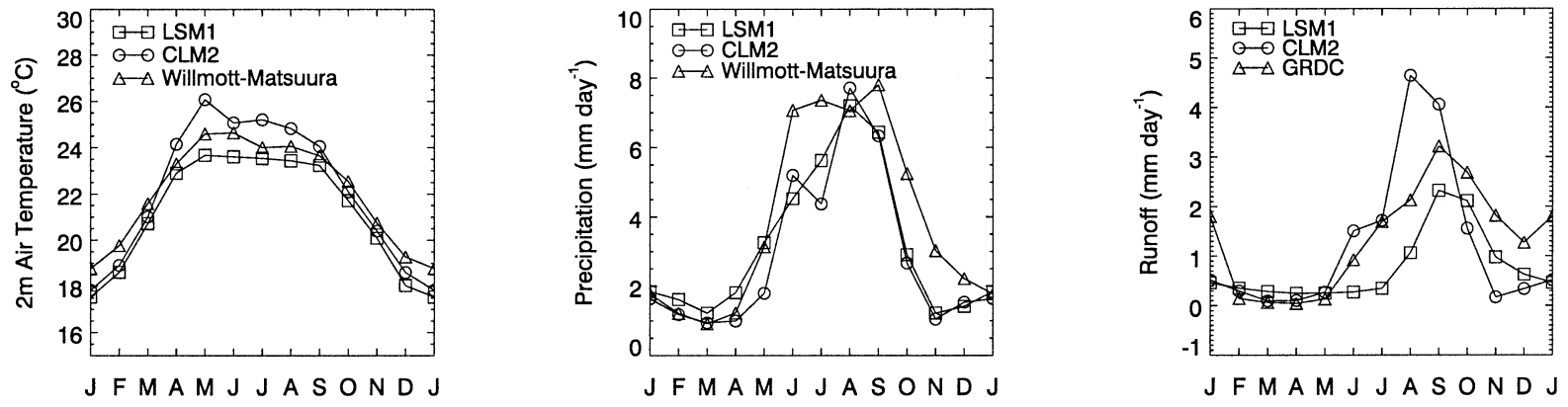

Amazon Basin 10S-Equator,70-50W
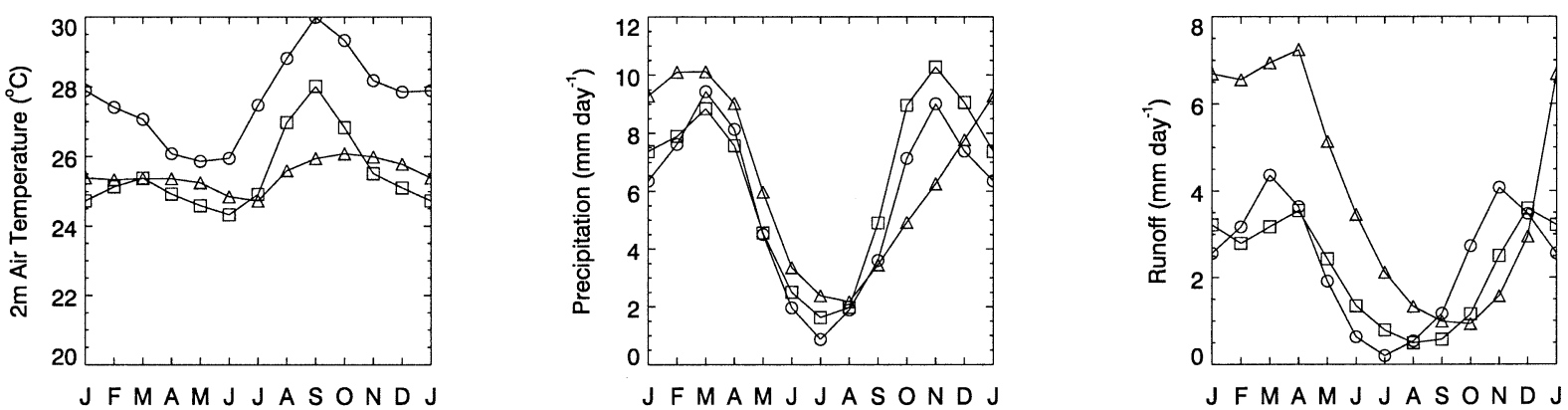

\section{Congo $10 \mathrm{~S}-5 \mathrm{~N}, 10-30 \mathrm{E}$}
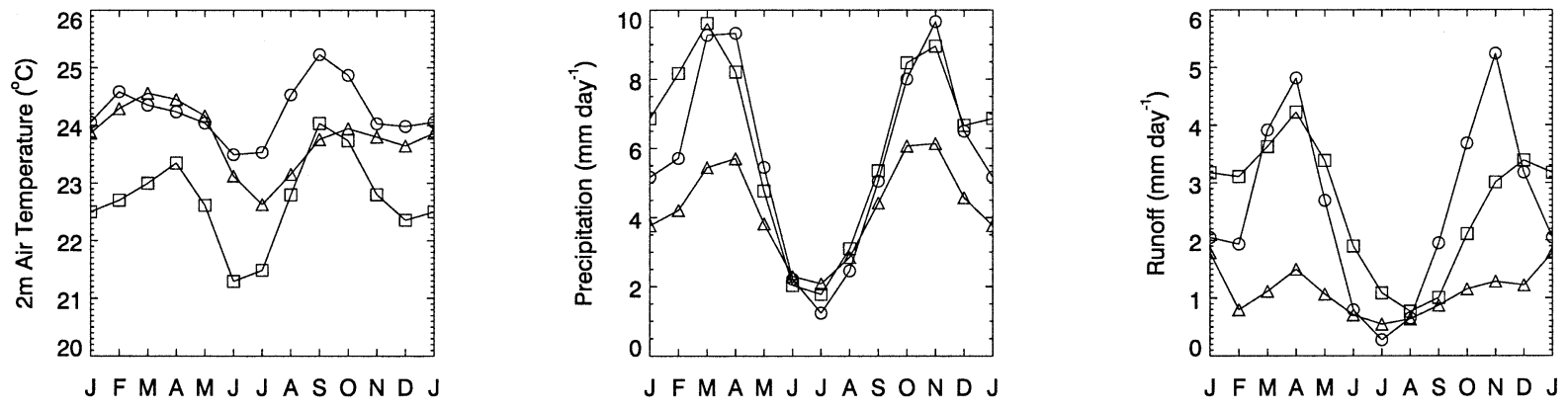

India 10-30N,70-90E
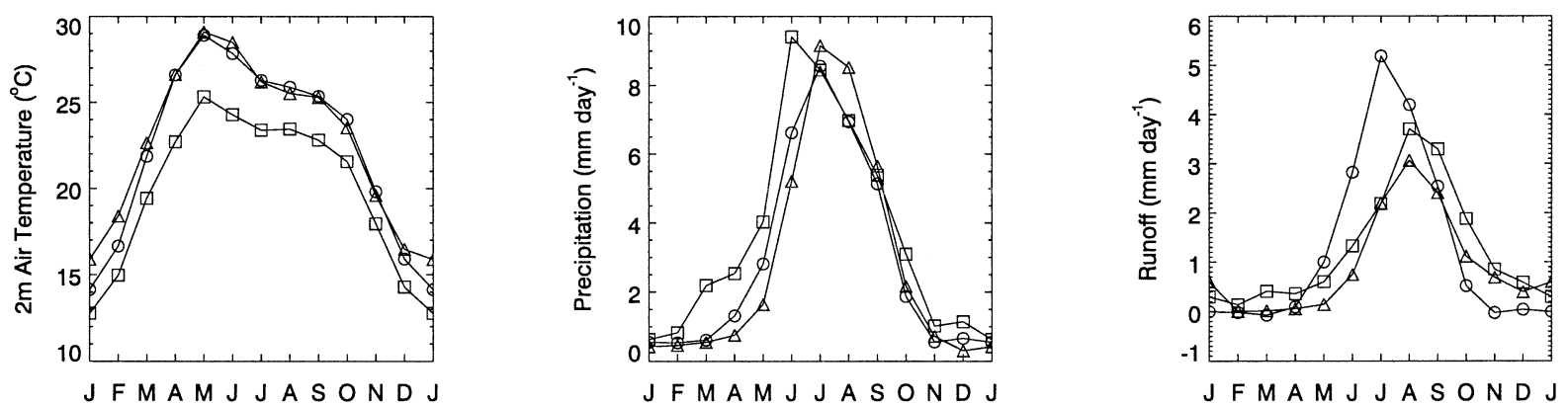

FIG. 10. As in Fig. 8 but for tropical latitudes. 


\section{Sahara + Arabian Peninsula 10-30N,20W-50E}

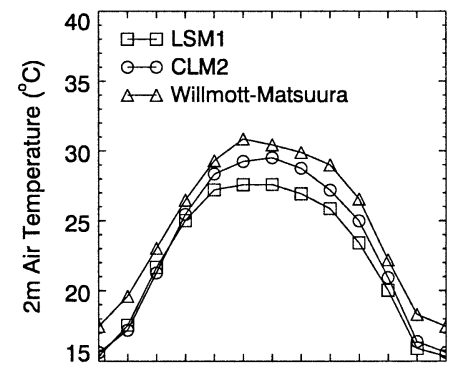

$J F M A M J J A S O N D J$
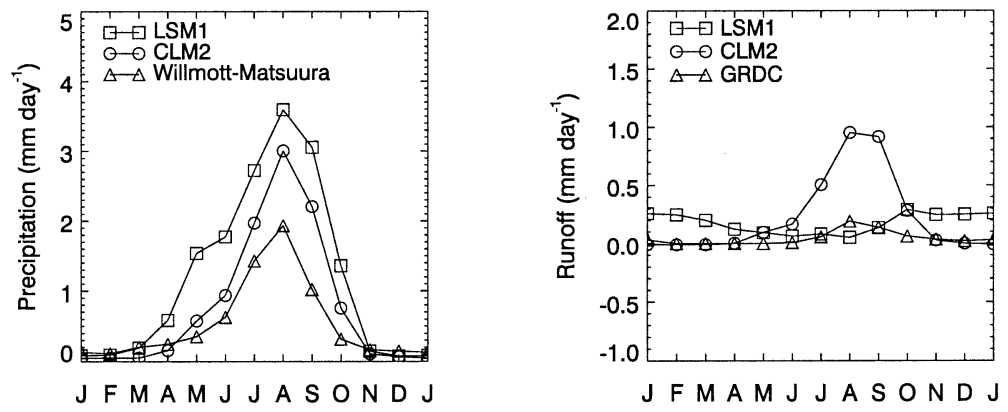

Southern South America 60-25S,80-50W
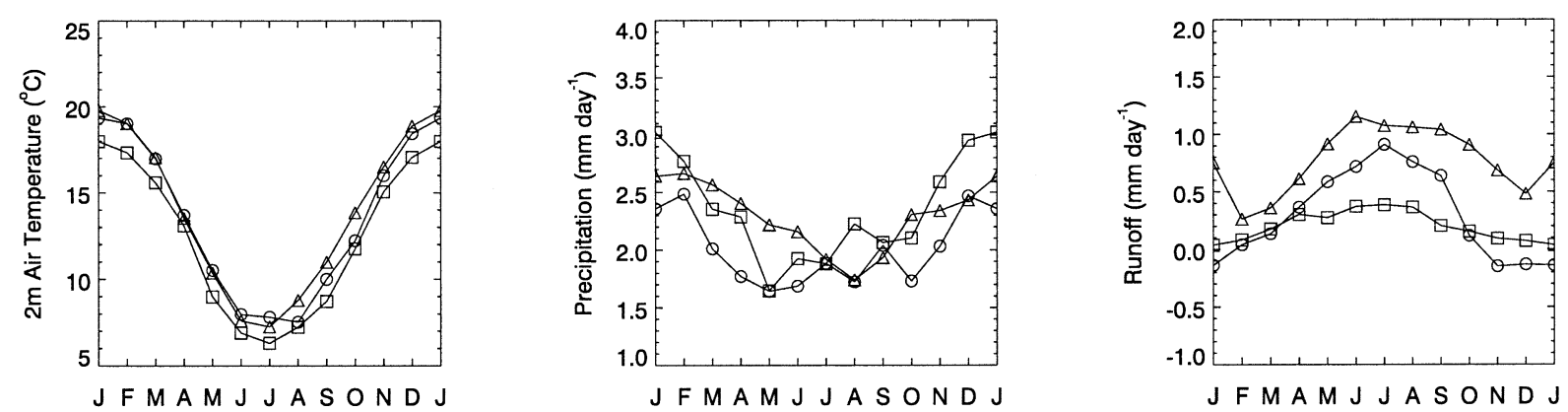

South Africa 35-10S, 10-40E
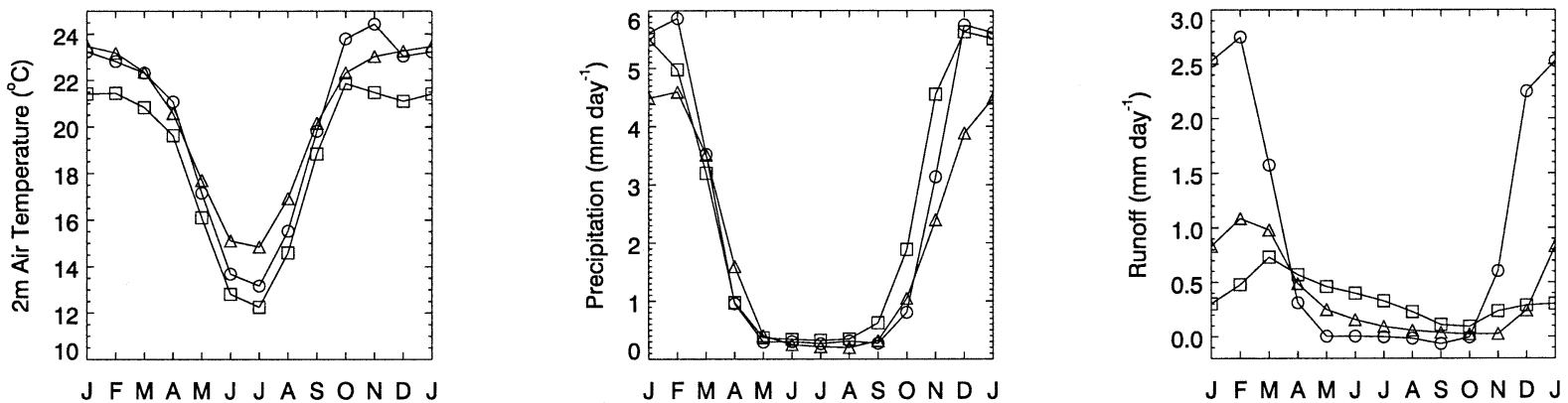

Australia 40-10S, 110-160E

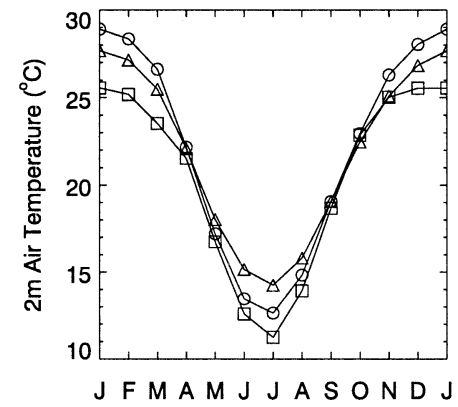

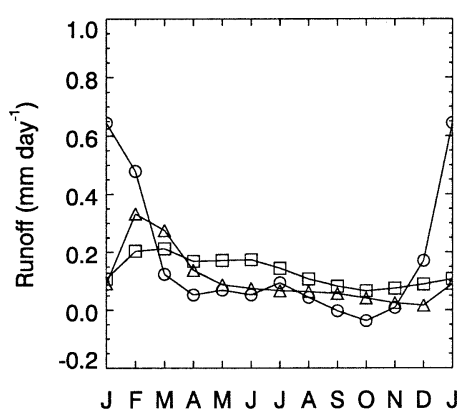

FIG. 11. As in Fig. 8 but for arid regions. 


\section{CLM2 - LSM2 Surface Air Temperature Difference}
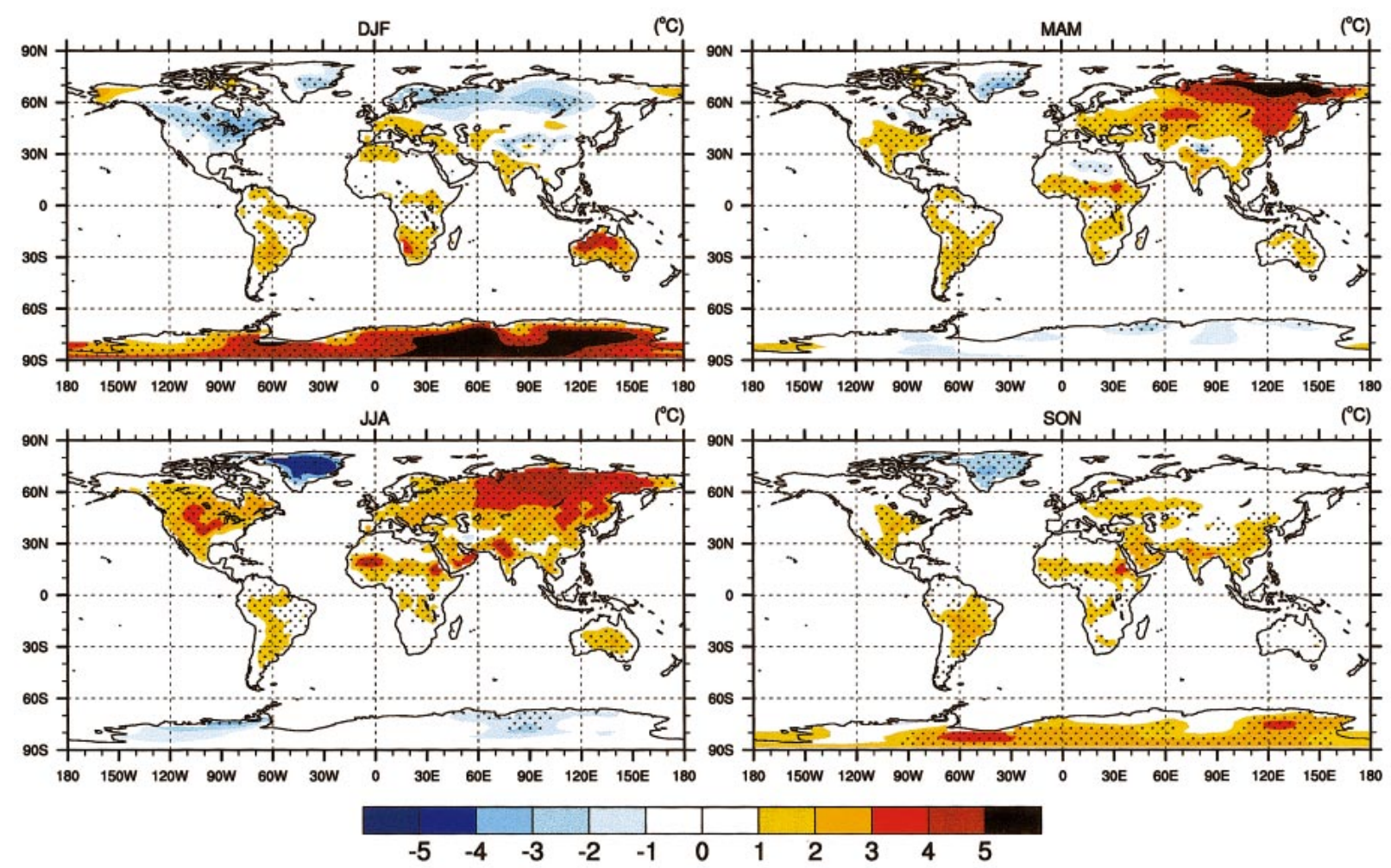

FIG. 12. Surface (2 m) air temperature difference between CLM2 and LSM2 (CLM2 - LSM2) for the four seasons (Dec-Feb, Mar-May, Jun-Aug, and Sep-Nov). Stippling shows regions where the difference is statistically significant based on a $t$ test $(p<0.05)$.

duced. The central United States illustrates the reduction in transpiration, increase in canopy evaporation, decrease in ground evaporation, and increases in sensible heat and net longwave loss also found in the eastern United States and central Europe (Fig. 18). The Amazon basin has similar changes, also seen in Central America, India, and the Congo (Fig. 19). Arid regions (e.g., southern Africa) also show reduced transpiration and ground evaporation and increased canopy evaporation with CLM2 (Fig. 20). In these arid regions, both latent and sensible heat decrease with CLM2 despite relatively little change in absorbed solar radiation. Instead, more energy is returned to the atmosphere as longwave radiation.

CLM2 and LSM1 differ substantially in the partitioning of latent heat into evaporation of intercepted water, transpiration, and ground evaporation. Leaves and stems evaporate more intercepted water annually in CLM2 than LSM1 (Table 8). This is a result of a greater proportion of precipitation intercepted for the same leaf and stem area (Fig. 2). Greater evaporation of intercepted water means that less precipitation reaches the ground to recharge the soil, contributing to drier soils in CLM2 compared to LSM1.

The reduction in transpiration with CLM2 is the result of several processes. The canopy integration scheme in
CLM2 reduces transpiration compared to LSM1. Fiveyear simulations of CLM2 coupled to CCM 3 and using either the LSM1 or CLM2 canopy integration parameterization show the reduction in transpiration due to the CLM2 parameterization contributes to the summer warm biases in the central United States and Europe (data not shown). This is also seen in regional analyses, which generally show reduced transpiration in LSM2 (which uses the same canopy integration as CLM2) compared to LSM1 (Figs. 17-20). However, the difference between CLM2 and LSM2 is generally greater than the difference between LSM2 and LSM1. One process that likely contributes to this is greater interception in CLM2. Transpiration is limited to dry leaves only, and high interception thereby restricts transpiration. In addition, less water reaches the ground, resulting in drier soil. This is accentuated by the different parameterization of soil water influence on stomata, which increases the degree to which soil water reduces transpiration in CLM2 compared to LSM1 (Fig. 3). Five-year simulations with CCM3 and CLM2 that used either the LSM1 soil water factor or the CLM2 soil water factor show the CLM2 parameterization reduces latent heat, increases sensible heat, and warms surface air temperature in the central United States, central Europe, and the Tropics in the June-August season (data not shown). 


\section{LSM2 - LSM1 Surface Air Temperature Difference}
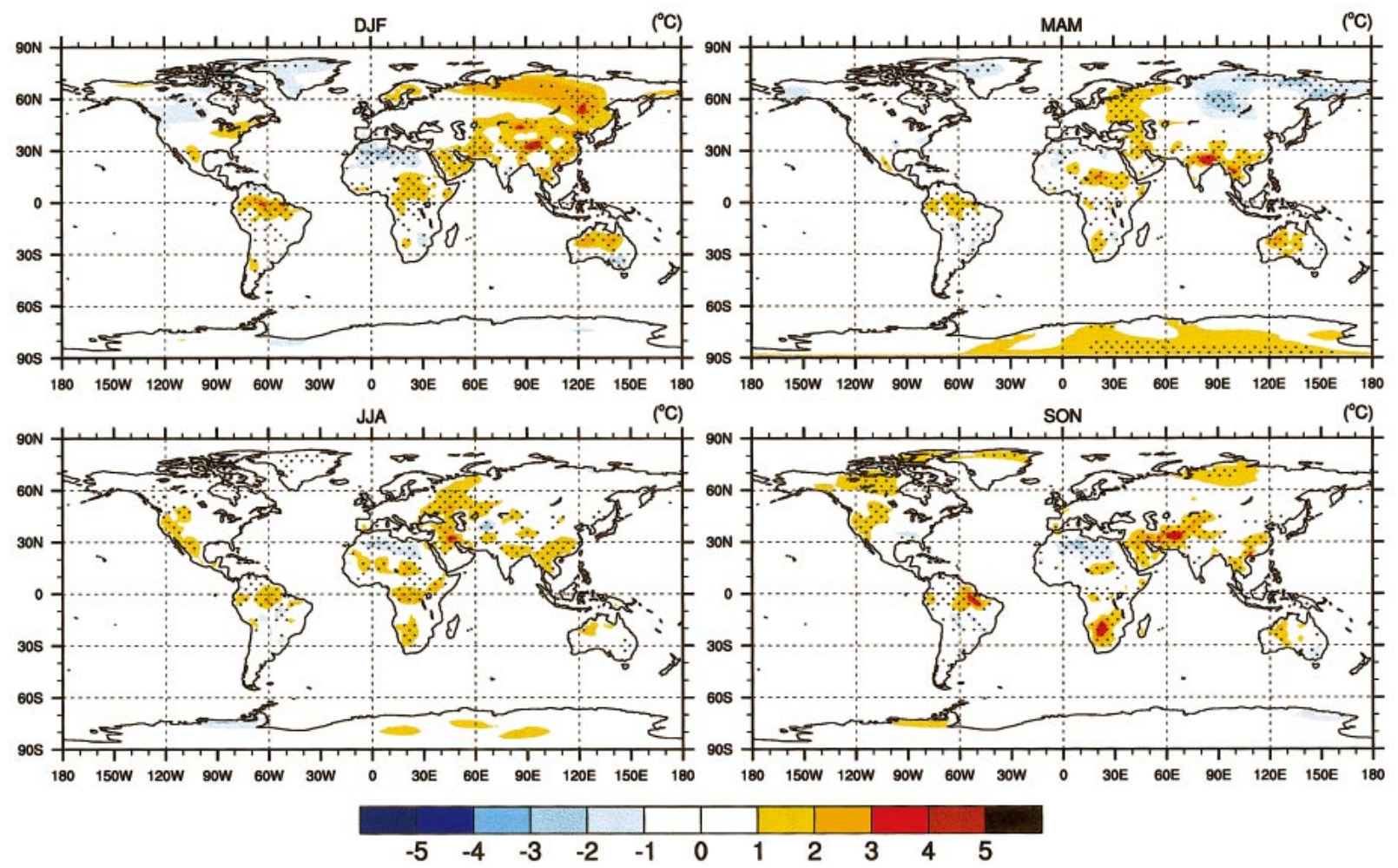

FIG. 13. As in Fig. 12 but for the LSM2 - LSM1 difference.

The reduction in ground evaporation arises from drier soil and several parameterization differences with LSM1. LSM1 uses a surface resistance to reduce saturated soil evaporation for soil water limitation. This resistance is similar to the effect of soil water on stomata, increasing only with very dry soil. CLM2 reduces ground evaporation not through a surface resistance but rather through the moisture gradient with the atmosphere, decreasing saturated soil specific humidity as the soil dries. This is parameterized as a nonlinear function of soil water. In addition, the aerodynamic resistance governing ground evaporation is higher in CLM2 than LSM1 (Fig. 4). For bare ground, this is because the roughness length of soil is smaller in CLM2. For vegetation, this is because of different assumptions about turbulent processes within a canopy.

\section{e. Hydrologic cycle}

The increased evaporation of intercepted water in CLM2 results in a different hydrologic cycle compared to LSM1. In LSM1, 5\%-13\% of annual precipitation is intercepted by the canopy and evaporated (Table 8). CLM2 intercepts 12\%-39\%. In the Amazon and Congo, more than one-third of the annual precipitation does not reach the soil. Elsewhere, evaporation of intercepted

TABLE 7. Surface energy balance $\left(\mathrm{W} \mathrm{m}^{-2}\right)$ for northern Eurasia $\left(50^{\circ}-70^{\circ} \mathrm{N}, 5^{\circ}-130^{\circ} \mathrm{E}\right)$ and North America $\left(40^{\circ}-60^{\circ} \mathrm{N}, 130^{\circ}-60^{\circ} \mathrm{W}\right)$ during the Dec-Feb season. Data are the LSM1 and CLM2 simulations.

\begin{tabular}{|c|c|c|c|c|}
\hline & \multicolumn{2}{|c|}{ Northern Eurasia } & \multicolumn{2}{|c|}{ North America } \\
\hline & LSM1 & CLM2 & LSM1 & CLM2 \\
\hline Incoming solar radiation, $S \downarrow$ & 21.3 & 19.1 & 51.2 & 49.4 \\
\hline Reflected solar radiation, $S \uparrow$ & 11.3 & 8.7 & 15.1 & 16.5 \\
\hline Absorbed solar radiation, $S \downarrow-S \uparrow$ & 10.0 & 10.4 & 36.1 & 32.8 \\
\hline Net longwave radiation $(\mathrm{L} \uparrow-\mathrm{L} \downarrow)$ & 23.6 & 19.4 & 41.1 & 35.2 \\
\hline Net radiation $(S \downarrow-S \uparrow+L \downarrow-L \uparrow)$ & -13.6 & -9.0 & -5.0 & -2.4 \\
\hline Latent heat & 4.2 & 5.1 & 8.2 & 8.7 \\
\hline Sensible heat & -6.9 & -6.7 & -1.4 & -3.6 \\
\hline Soil heat & -11.7 & -8.2 & -13.9 & -9.5 \\
\hline Snowmelt & 0.7 & 0.8 & 2.1 & 2.1 \\
\hline
\end{tabular}




\section{CLM2 - LSM1 Precipitation Difference}

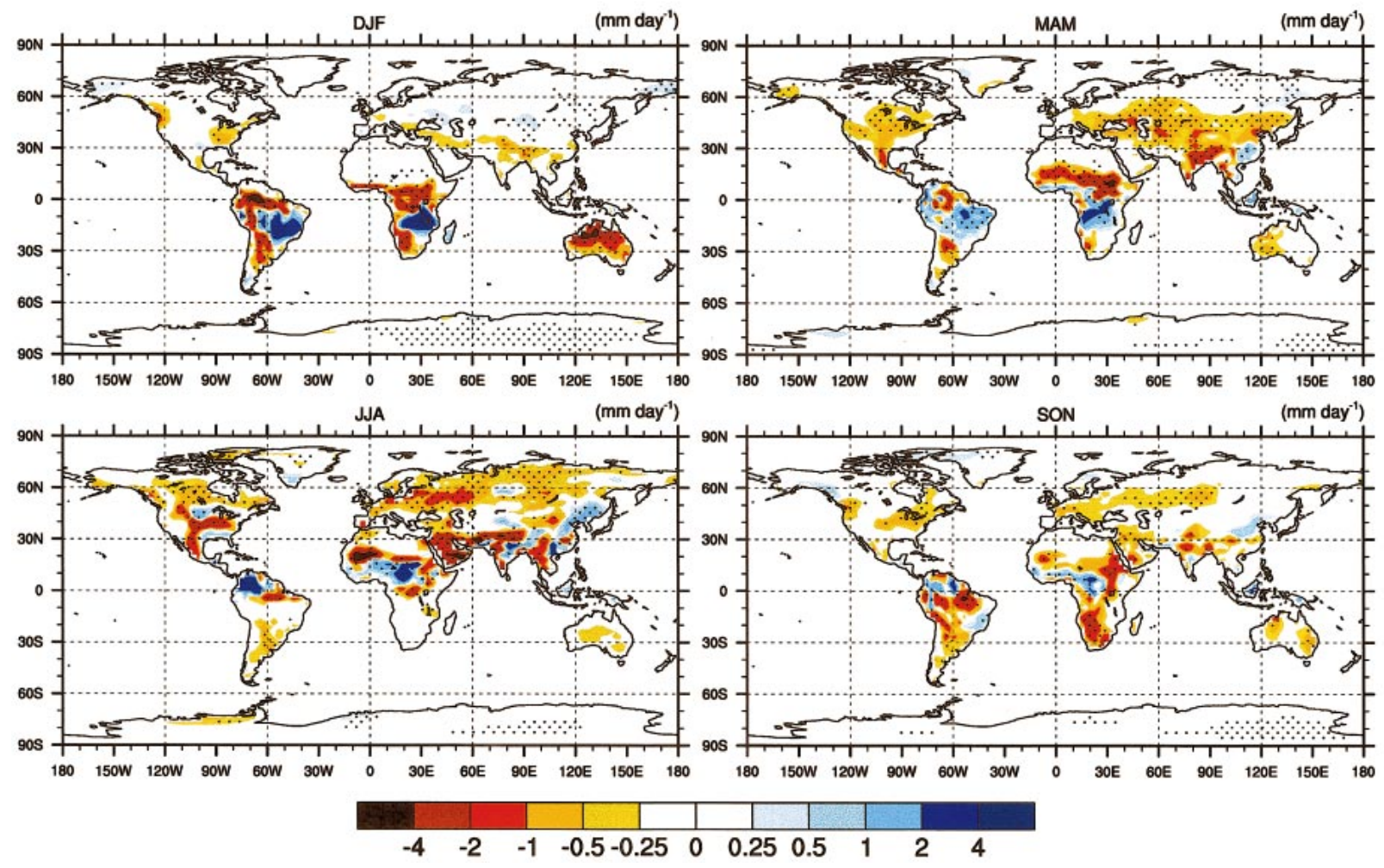

FIG. 14. Precipitation difference between CLM2 and LSM1 (CLM2 - LSM1) for the four seasons (Dec-Feb, Mar-May, Jun-Aug, and Sep-Nov). Stippling shows regions where the difference is statistically significant based on a $t$ test $(p<0.05)$.

water generally ranges from $20 \%$ to $25 \%$ of annual precipitation. Although both models have the same maximum water storage capacity $(0.1 \mathrm{~mm}$ per unit leaf and stem area index), LSM1 limits interception to, at most, $20 \%$ of precipitation during any time step while CLM2 allows a considerably greater portion of precipitation to be intercepted (Fig. 2). In addition, LSM1 distinguishes large-scale precipitation, which occurs over the entire grid cell, from convective precipitation, which is limited to a smaller portion of the grid cell. The high percent of annual precipitation evaporated from the canopy by CLM2 exceeds generally reported values (Bonan 2002) and likely indicates a need to account for subgrid-scale representation of precipitation in CLM2.

In addition to substantially reducing the water reaching the ground, CLM2 differs from LSM1 in the fate of this water. A higher fraction of water reaching the ground is lost as surface runoff or subsurface drainage in CLM2 (Table 8). Global runoff from land increases from $0.75 \mathrm{~mm} \mathrm{day}{ }^{-1}$ (32\% of annual precipitation) in LSM1 to $0.84 \mathrm{~mm} \mathrm{day}^{-1}$ (39\% of annual precipitation) in CLM2 despite decreased precipitation. This compares to Baumgartner and Reichel's (1975) estimate of 0.73 $\mathrm{mm}$ day $^{-1}$. Excluding glaciers, total runoff from land increases from $0.78 \mathrm{~mm}$ day $^{-1}$ in LSM1 to $0.93 \mathrm{~mm}$ day $^{-1}$ in CLM2. This is higher than the global value of
$0.82 \mathrm{~mm}$ day $^{-1}$ derived from the UNH-GRDC dataset (Fekete et al. 2000), which has no data over glaciers. Greater runoff reduces the soil water available for evapotranspiration. This is especially evident in the central United States, central Europe, and the Amazon, where runoff is 2-3 times higher in CLM2. Dry soil in these regions likely contributes to the warm temperature bias (Fig. 7).

The seasonality of runoff is much improved compared to LSM1. In arctic and boreal regions, LSM1 has negligible seasonal variation in runoff (Fig. 8). Observations have a pronounced peak during the snowmelt season, which is better captured by CLM2. In addition, runoff in CLM2 is less than LSM1 and closer to observations during the cold season. This is likely due to the accounting of frozen and unfrozen water in CLM2. Drainage is reduced if ice exists in the soil column. In contrast, LSM1 allows drainage regardless of the thermal state of the soil. Similar improvements are seen in midlatitude regions such as the central and eastern United States, and central Europe (Fig. 9). In these regions, however, cold season hydrology is less important. Instead, the exponential decay of saturated hydraulic conductivity and the new 10-layer soil water parameterization in CLM2 result in phase shifts in runoff compared to LSM1. Differences between models are less apparent 


\section{CLM2 - Willmott/Matsuura Precipitation Difference}

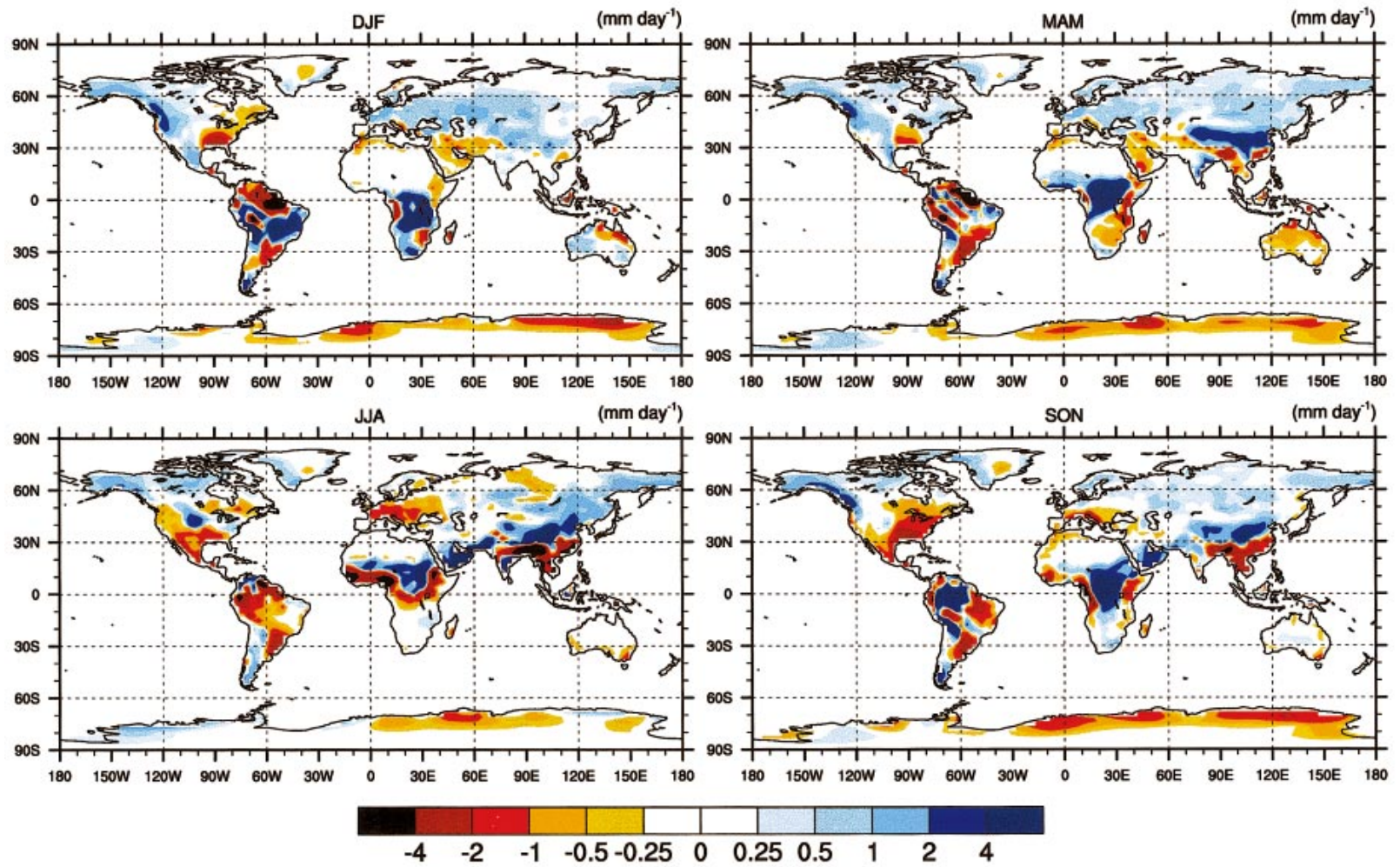

FIG. 15. CLM2 precipitation bias compared to the Willmott and Matsuura (2000) observations for the four seasons.

TABle 8. Annual hydrologic cycle: $P$ indicates precipitation; CE, evaporation of water intercepted by the canopy; $T$, transpiration; GE, ground evaporation; $R$, total runoff. Here $\mathrm{CE}$ is given as a percent of precipitation; $T$, GE, and $R$ are given as a percent of water reaching the ground $(P-\mathrm{CE})$. Regions are defined in Figs. 8-11.

\begin{tabular}{|c|c|c|c|c|c|c|c|c|c|c|}
\hline \multirow[b]{2}{*}{ Region } & \multicolumn{2}{|c|}{$P(\mathrm{~mm})$} & \multicolumn{2}{|c|}{$\mathrm{CE}(\% P)$} & \multicolumn{2}{|c|}{$T(\% P-\mathrm{CE})$} & \multicolumn{2}{|c|}{$\mathrm{GE}(\% P-\mathrm{CE})$} & \multicolumn{2}{|c|}{$R(\% P-\mathrm{CE})$} \\
\hline & LSM1 & CLM2 & LSM1 & CLM2 & LSM1 & CLM2 & LSM1 & CLM2 & LSM1 & CLM2 \\
\hline \multicolumn{11}{|c|}{ Arctic and boreal } \\
\hline $\begin{array}{l}\text { Alaska and } \\
\text { northwestern Canada }\end{array}$ & 798 & 755 & 7 & 15 & 6 & 3 & 26 & 20 & 66 & 75 \\
\hline Northern Europe & 759 & 700 & 9 & 22 & 9 & 9 & 28 & 22 & 62 & 68 \\
\hline West Siberia & 673 & 600 & 6 & 19 & 9 & 10 & 41 & 42 & 48 & 48 \\
\hline East Siberia & 566 & 541 & 8 & 24 & 8 & 11 & 39 & 26 & 51 & 62 \\
\hline \multicolumn{11}{|c|}{ Midlatitudes } \\
\hline Western United States & 682 & 597 & 8 & 16 & 14 & 10 & 36 & 21 & 50 & 68 \\
\hline Central United States & 688 & 570 & 9 & 28 & 25 & 20 & 67 & 55 & 8 & 24 \\
\hline Eastern United States & 952 & 848 & 8 & 27 & 24 & 22 & 50 & 43 & 25 & 34 \\
\hline Central Europe & 815 & 687 & 6 & 22 & 18 & 17 & 51 & 34 & 28 & 49 \\
\hline \multicolumn{11}{|c|}{ Tropics } \\
\hline Central America & 1192 & 1080 & 12 & 29 & 37 & 16 & 35 & 22 & 27 & 61 \\
\hline India & 1395 & 1105 & 6 & 12 & 13 & 8 & 50 & 40 & 36 & 51 \\
\hline Amazon & 2292 & 2058 & 13 & 39 & 44 & 15 & 15 & 15 & 39 & 68 \\
\hline Congo & 2244 & 2128 & 12 & 35 & 34 & 14 & 17 & 17 & 47 & 68 \\
\hline \multicolumn{11}{|c|}{ Arid } \\
\hline Sahara Desert & 465 & 303 & 6 & 12 & 18 & 4 & 68 & 63 & 14 & 33 \\
\hline Southern South America & 845 & 723 & 5 & 25 & 11 & 16 & 80 & 62 & 9 & 21 \\
\hline Southern Africa & 869 & 817 & 8 & 24 & 22 & 13 & 61 & 38 & 16 & 48 \\
\hline Australia & 569 & 374 & 9 & 22 & 22 & 16 & 69 & 67 & 9 & 17 \\
\hline Global land & 858 & 779 & 8 & 23 & 21 & 11 & 43 & 34 & 35 & 51 \\
\hline
\end{tabular}


North America Monthly Snow Cover
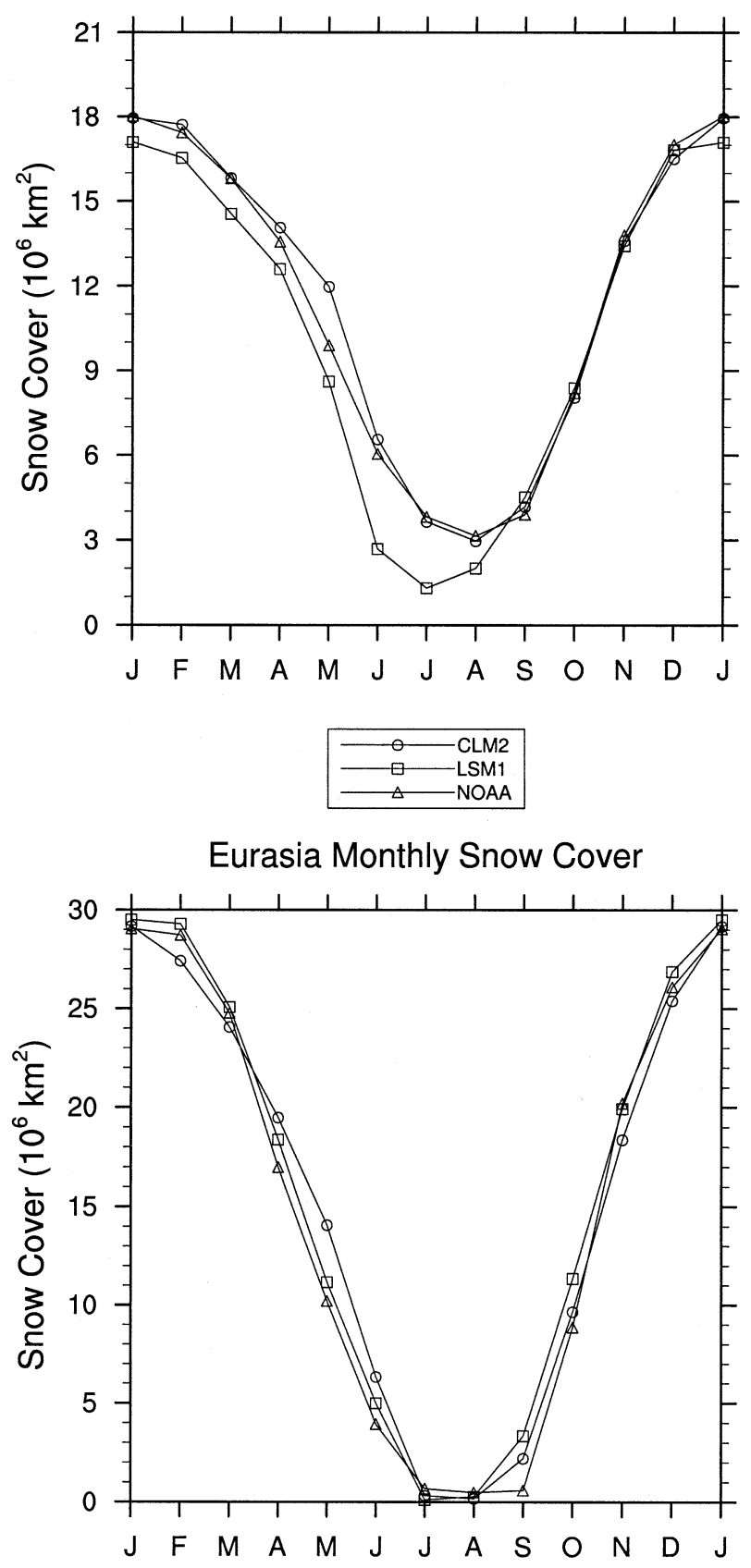

FIG. 16. Monthly snow cover for North America (including Greenland) and Eurasia for LSM1 and CLM2. Observations are from the NSIDC (1996a,b) Northern Hemisphere climatology for the period 1971-95. in the Tropics, where both models reproduce the seasonality of runoff (Fig. 10). CLM2 generally has more runoff than LSM1 during the rainy season. This difference is also seen in arid regions (Fig. 11).

\section{Conclusions}

The surface physics and hydrology of the community land model for use with the community climate system model has been greatly updated from the NCAR LSM. This reflects new ideas formulated by Zeng et al. (2002) in the common land model and by Bonan et al. (2002) to allow coupling to terrestrial ecosystems models. Major model differences include the abandonment of the biome classification of surface types and inclusion of a subgrid mosaic of land cover types and plant functional types; satellite-derived land cover, plant type, and leaf area index datasets; 10 soil layers with explicit treatment of liquid water and ice; a multilayer snowpack; runoff based on the TOPMODEL concept; new formulation of ground and vegetation fluxes; and vertical root profiles from a global synthesis of ecological studies.

CLM2 generally warms surface air temperature in all seasons compared to LSM1, reducing or eliminating many cold biases. In particular, the prominent Northern Hemisphere summer cold bias of LSM1 has been eliminated due to reduced latent heat and increased sensible heat. Reduced latent heat also likely contributes to the reduced precipitation seen in CLM2. Reduction in latent heat arises from reduced transpiration and ground evaporation but increased evaporation of water intercepted by the canopy. This reflects increased soil water limitation to transpiration, higher aerodynamic resistances to heat exchange from the ground, and greater interception in CLM2 compared to LSM1. New snow parameterizations, including a multilayer snowpack, result in improved simulation of snow depth and snow cover. Runoff increases in CLM2 compared to LSM1 despite reduced precipitation. However, the annual cycle of runoff is greatly improved in CLM2, especially in arctic and boreal regions where the inclusion of cold season hydrology improves the annual cycle of runoff.

Acknowledgments. The work of Gordon Bonan and Keith Oleson was supported by the NASA Land Cover Land Use Change program through interagency Contract W-19,735. The work of Zong-Liang Yang was supported by NSF Grant ATM-0095094.

TABLE 9. Global annual average (land only) surface energy fluxes $\left(\mathrm{W} \mathrm{m}^{-2}\right)$.

\begin{tabular}{lccccccc}
\hline \hline & & & \multicolumn{3}{c}{ Latent heat } \\
\cline { 5 - 8 } & $\begin{array}{c}\text { Absorbed solar } \\
\text { radiation }\end{array}$ & $\begin{array}{c}\text { Net longwave } \\
\text { loss }\end{array}$ & Sensible heat & Total & $\begin{array}{c}\text { Canopy } \\
\text { evaporation }\end{array}$ & $\begin{array}{c}\text { Transpiration } \\
\text { evaporation }\end{array}$ \\
\hline LSM1 & 142.4 & 65.5 & 30.3 & 46.0 & 6.0 & 13.3 & 26.7 \\
CLM2 & 148.0 & 81.0 & 31.1 & 35.8 & 14.4 & 5.2 & 16.2 \\
\hline
\end{tabular}



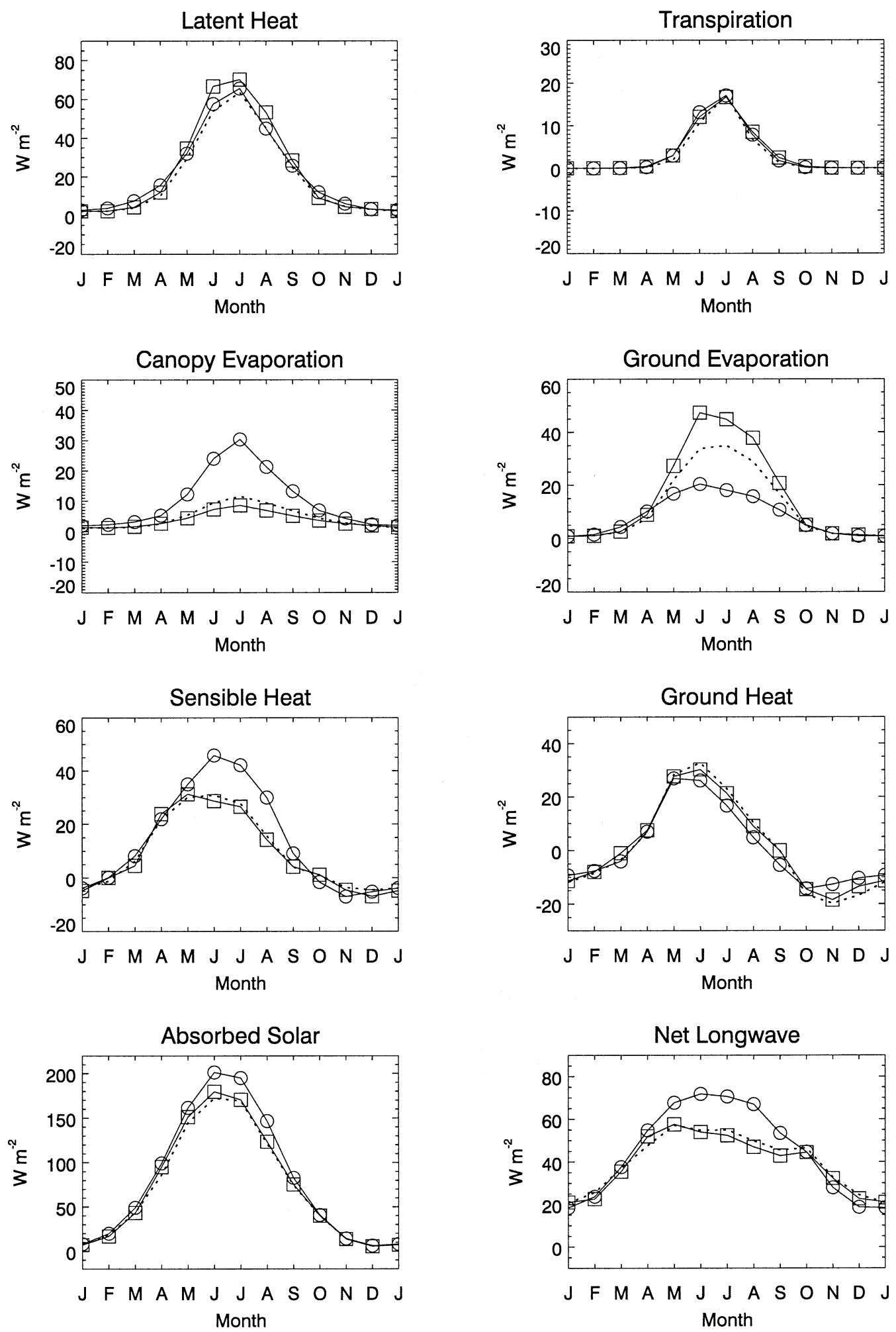

FIG. 17. Regionally averaged monthly surface energy fluxes for LSM1 (squares), LSM2 (dotted line), and CLM2 (circles) in eastern Siberia. Latent heat is partitioned into transpiration, evaporation of water intercepted by the canopy, and ground evaporation. Net longwave is the net loss to the atmosphere. 

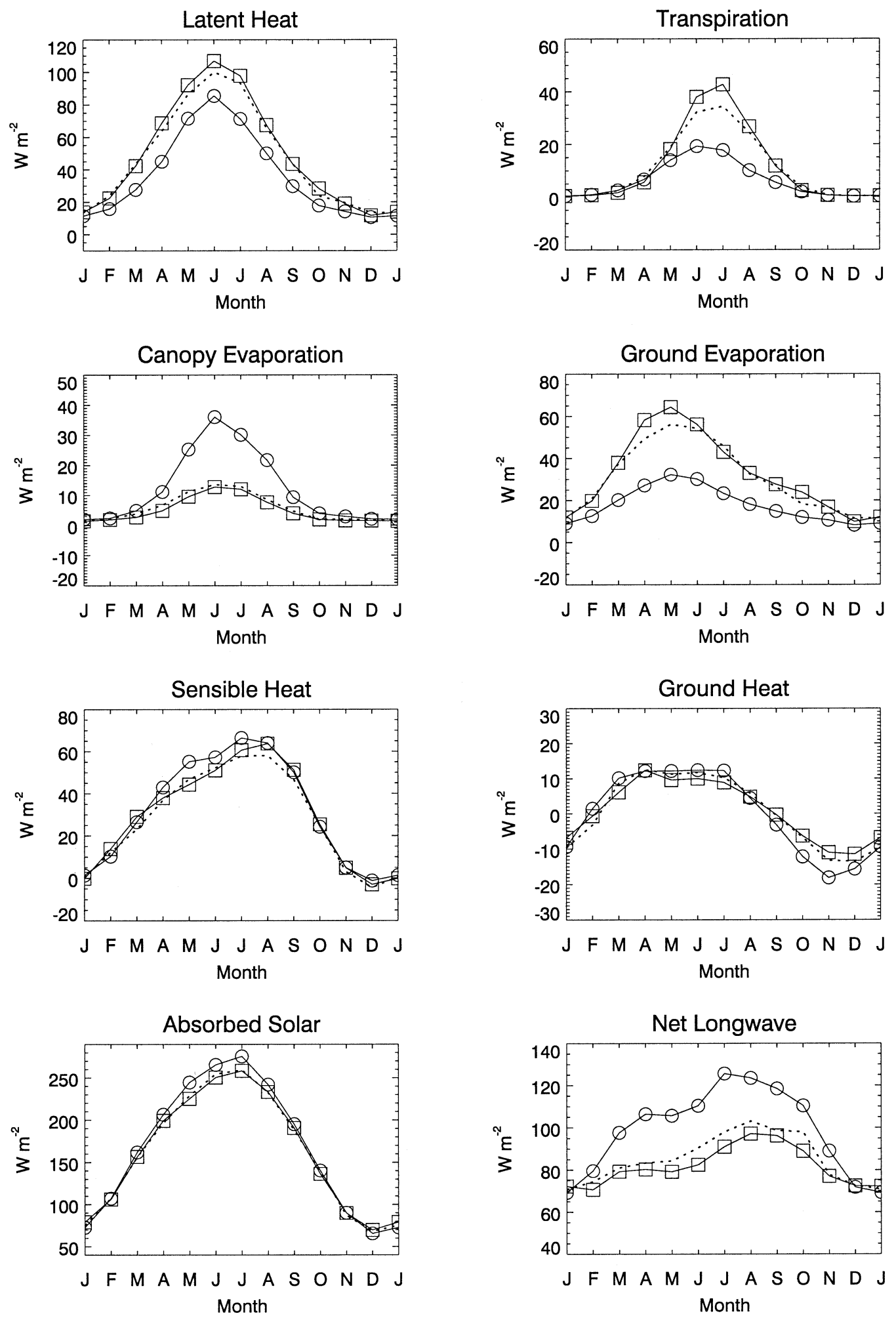

FIG. 18. As in Fig. 17 but for the central United States. 

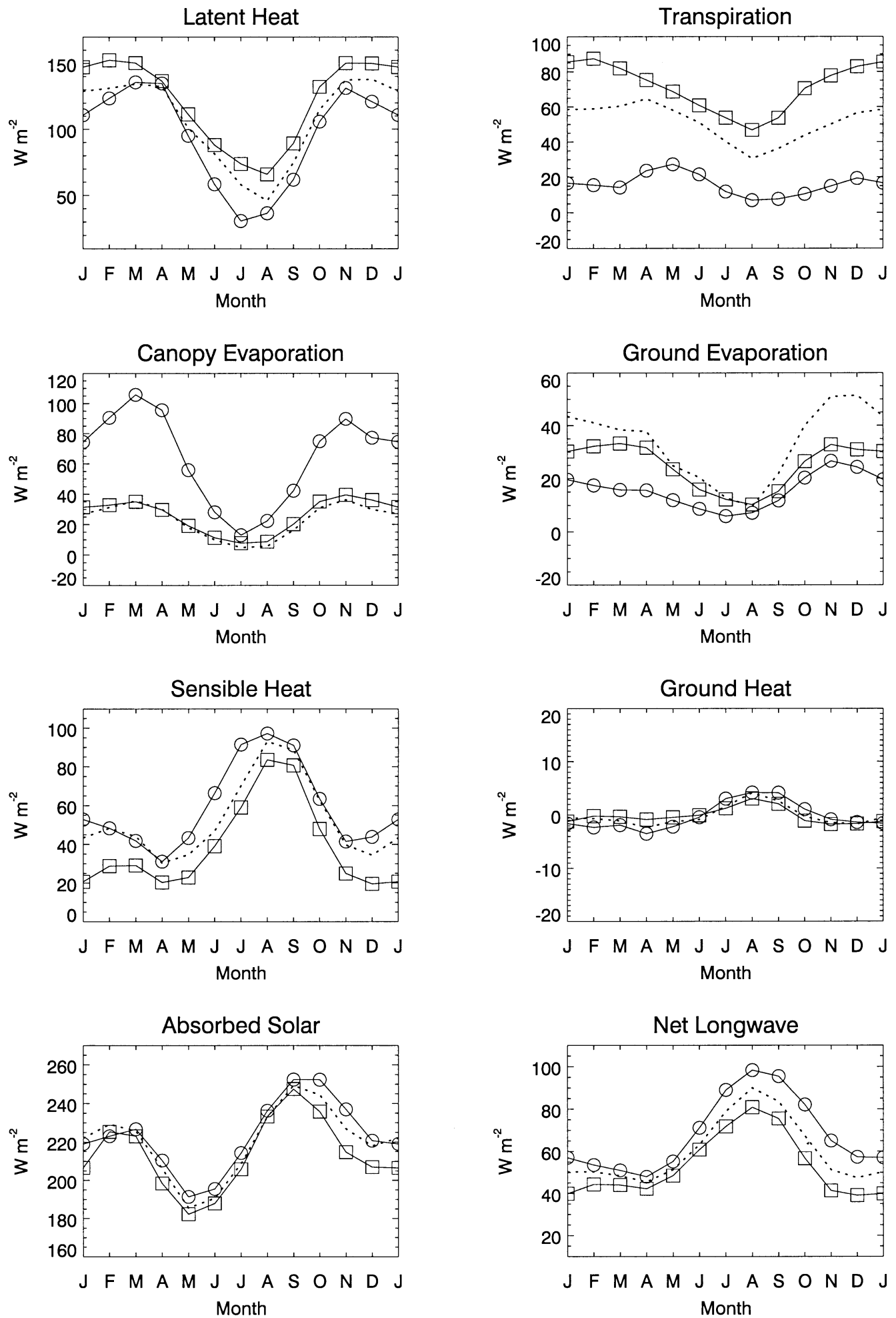

FIG. 19. As in Fig. 17 but for the Amazon. 

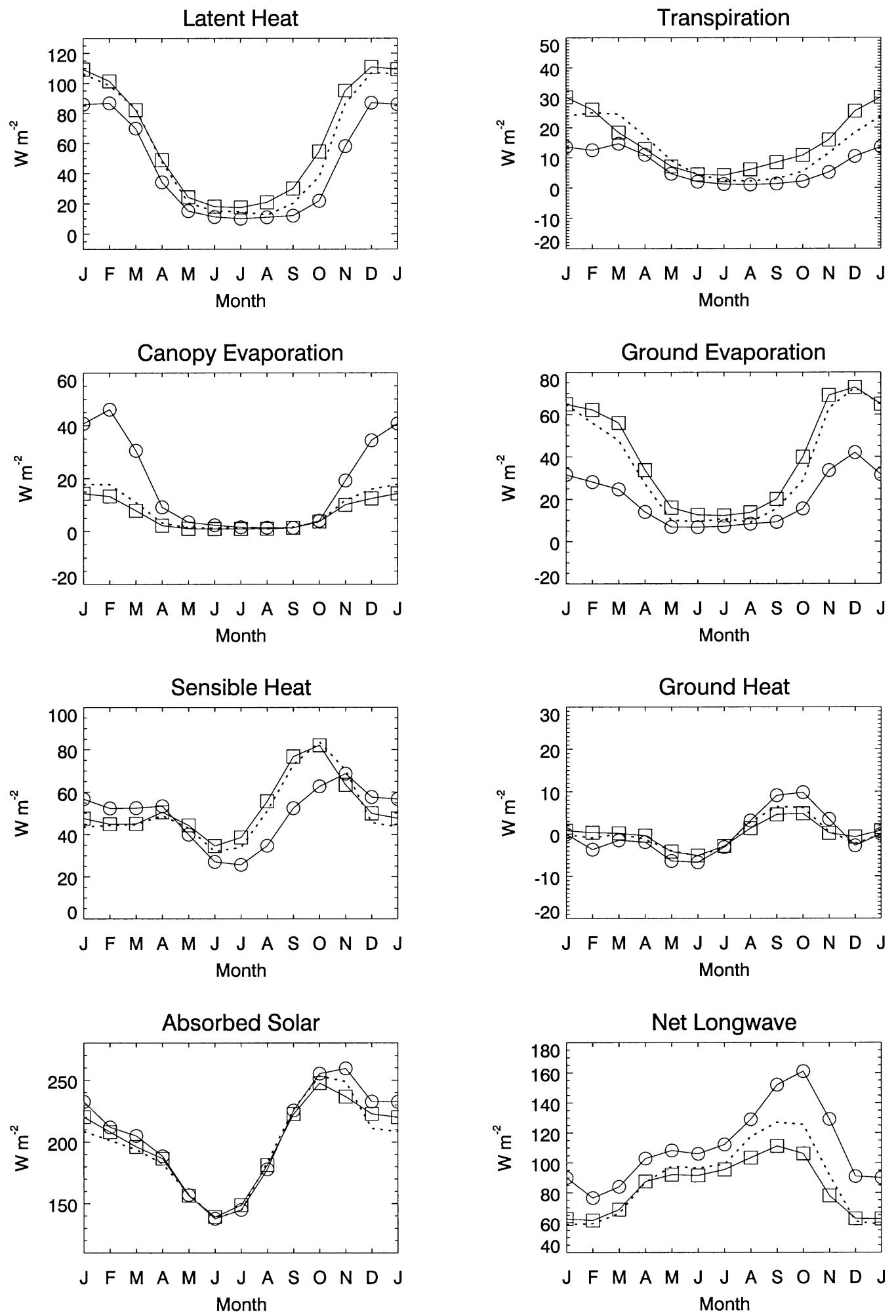

FIG. 20. As in Fig. 17 but for southern Africa. 


\section{REFERENCES}

Baumgartner, A., and E. Reichel, 1975: The World Water Balance: Mean Annual Global, Continental and Maritime Precipitation, Evaporation, and Run-off. Elsevier, 179 pp.

Beringer, J., A. H. Lynch, F. S. Chapin III, M. Mack, and G. B. Bonan, 2001: The representation of Arctic soils in the land surface model: The importance of mosses. J. Climate, 14, 3324 3335 .

Beven, K. J., and M. J. Kirkby, 1979: A physically based variable contributing area model of basin hydrology. Hydrol. Sci. Bull., 24, 43-69.

Bonan, G. B., 1991a: A biophysical surface energy budget analysis of soil temperature in the boreal forests of interior Alaska. Water Resour. Res., 27, 767-781.

1991b: Atmosphere-biosphere exchange of carbon dioxide in boreal forests. J. Geophys. Res., 96D, 7301-7312.

- 1991c: Seasonal and annual carbon fluxes in a boreal forest landscape. J. Geophys. Res., 96D, 17 329-17 338.

, 1992: Comparison of atmospheric carbon dioxide concentration and metabolic activity in boreal forest ecosystems. Tellus, 44B, 173-185.

_ - 1993a: Importance of leaf area index and forest type when estimating photosynthesis in boreal forests. Remote Sens. Environ., 43, 303-314.

_ 1993b: Physiological controls of the carbon balance of boreal forest ecosystems. Can. J. For. Res., 23, 1453-1471.

_ $1993 \mathrm{c}$ : Physiological derivation of the observed relationship between net primary production and mean annual air temperature. Tellus, 45B, 397-408.

— 1995a: Land-atmosphere $\mathrm{CO}_{2}$ exchange simulated by a land surface process model coupled to an atmospheric general circulation model. J. Geophys. Res., 100D, 2817-2831.

— 1995b: Sensitivity of a GCM simulation to inclusion of inland water surfaces. J. Climate, 8, 2691-2704.

, 1996: A land surface model (LSM ver. 1.0) for ecological, hydrological, and atmospheric studies: Technical description and user's guide. NCAR Tech. Note 417+STR, 150 pp. [Available from NCAR, P.O. Box 3000, Boulder, CO 80307.]

_ 1997: Effects of land use on the climate of the United States. Climatic Change, 37, 449-486.

_ 1998: The land surface climatology of the NCAR land surface model coupled to the NCAR Community Climate Model. J. Climate, 11, 1307-1326.

- 1999: Frost followed the plow: Impacts of deforestation on the climate of the United States. Ecol. Appl., 9, 1305-1315.

—- 2002: Ecological Climatology: Concepts and Applications. Cambridge University Press, 678 pp.

— of floods and droughts in the Mississippi River Basin. Water Resour. Res., 34, 2693-2701.

— K. J. Davis, D. Baldocchi, D. Fitzjarrald, and H. Neumann, 1997: Comparison of the NCAR LSM1 land surface model with BOREAS aspen and jack pine tower fluxes. J. Geophys. Res., 102D, 29 065-29075.

— - S. Levis, L. Kergoat, and K. W. Oleson, 2002: Landscapes as patches of plant functional types: An integrating concept for climate and ecosystem models. Global Biogeochem. Cycles, 16, 5.1-5.23.

Carrington, D. P., R. G. Gallimore, and J. E. Kutzbach, 2001: Climate sensitivity to wetlands and wetland vegetation in mid-Holocene North Africa. Climate Dyn., 17, 151-157.

Coe, M. T., and G. B. Bonan, 1997: Feedbacks between climate and surface water in northern Africa during the middle Holocene. $J$. Geophys. Res., 102D, 11 087-11 101

Craig, S. G., K. J. Holmén, G. B. Bonan, and P. J. Rasch, 1998: Atmospheric $\mathrm{CO}_{2}$ simulated by the National Center for Atmospheric Research Community Climate Model 1: Mean fields and seasonal cycles. J. Geophys. Res., 103D, 13 213-13 235.

Cramer, W., and Coauthors, 2001: Global response of terrestrial eco- system structure and function to $\mathrm{CO}_{2}$ and climate change: Result from six dynamic global vegetation models. Global Change Biol., 7, 357-373.

Dai, Y., and Q.-C. Zeng, 1997: A land surface model (IAP94) for climate studies. Part I: Formulation and validation in off-line experiments. Adv. Atmos. Sci., 14, 433-460.

DeFries, R. S., J. R. G. Townshend, and M. C. Hansen, 1999: Continuous fields of vegetation characteristics at the global scale at 1-km resolution. J. Geophys. Res., 104D, 16 911-16923.

- M. C. Hansen, and J. R. G. Townshend, 2000a: Global continuous fields of vegetation characteristics: A linear mixture model applied to multi-year $8 \mathrm{~km}$ AVHRR data. Int. J. Remote Sens., 21, 1389-1414.

_- A. C. Janetos, and T. R. Loveland, 2000b: A new global 1-km dataset of percentage tree cover derived from remote sensing. Global Change Biol., 6, 247-254.

Dickinson, R. E., A. Henderson-Sellers, and P. J. Kennedy, 1993: Biosphere-atmosphere transfer scheme (BATS) version 1e as coupled to the NCAR Community Climate Model. NCAR Tech. Note 387+STR, 72 pp. [Available from NCAR, P.O. Box 3000, Boulder, CO 80307.]

Fekete, B. M., C. J. Vörösmarty, and W. Grabs, cited 2000: Global composite runoff fields based on observed river discharge and simulated water balances. [Available online at http:// www.grdc.sr.unh.edu.]

Foster, J., and Coauthors, 1996: Snow cover and snow mass intercomparisons of general circulation models and remotely sensed datasets. J. Climate, 9, 409-426.

Global Soil Data Task, cited 2000: Global soil data products CDROM (IGBP-DIS). International Geosphere-Biosphere Programme-Data and Information Available Services. [Available online at http://www.daac.ornl.gov.]

Kiehl, J. T., J. J. Hack, G. B. Bonan, B. A. Boville, B. P. Briegleb, D. L. Williamson, and P. J. Rasch, 1996: Description of the NCAR Community Climate Model (CCM3). NCAR Tech. Note 420+STR, 152 pp. [Available from NCAR, P.O. Box 3000, Boulder, CO 80307.]

- - D. L. Williamson, and P. J. Rasch, 1998 The National Center for Atmospheric Research Community Climate Model: CCM3. J. Climate, 11, 1131-1149.

Kutzbach, J., G. Bonan, J. Foley, and S. P. Harrison, 1996: Vegetation and soil feedbacks on the response of the African monsoon to orbital forcing in the early to middle Holocene. Nature, 384, 623-626.

Legates, D. R., and C. J. Willmott, 1990a: Mean seasonal and spatial variability in global surface air temperature. Theor. Appl. Climatol., 41, 11-21.

— gauge-corrected, global precipitation. Int. J. Climatol., 10, 111127.

Loveland, T. R., B. C. Reed, J. F. Brown, D. O. Ohlen, Z. Zhu, L. Yang, and J. W. Merchant, 2000: Development of a global land cover characteristics database and IGBP DISCover from $1 \mathrm{~km}$ AVHRR data. Int. J. Remote Sens., 21, 1303-1330.

Lynch, A. H., and W. Wu, 2000: Impacts of fire and warming on ecosystem uptake in the boreal forest. J. Climate, 13, 23342338

— D. L. McGinnis, and D. A. Bailey, 1998: Snow-albedo feedback and the spring transition in a regional climate system model: Influence of land surface model. J. Geophys. Res., 103D, 29 037-29049.

- G. B. Bonan, F. S. Chapin III, and W. Wu, 1999a: The impact of tundra ecosystems on the surface energy budget and climate of Alaska. J. Geophys. Res., 104D, 6647-6660.

- F. S. Chapin III, L. D. Hinzman, W. Wu, E. Lilly, G. Vourlitis, and E. Kim, 1999b: Surface energy balance on the Arctic tundra: Measurements and models. J. Climate, 12, 2585-2606.

— S. McIlwaine, J. Beringer, and G. B. Bónan, 2001: An investigation of the sensitivity of a land surface model to climate 
change using a reduced form model. Climate Dyn., 17, 643652.

McGuire, A. D., and Coauthors, 2001: Carbon balance of the terrestrial biosphere in the twentieth century: Analyses of $\mathrm{CO}_{2}$, climate and land use effects with four process-based ecosystem models. Global Biogeochem. Cycles, 15, 183-206.

National Snow and Ice Data Center, 1996a: Northern Hemisphere EASE-grid weekly snow cover and sea ice content. Volume 1.0 January 4, 1971-January 1, 1978. [Available from National Snow and Ice Data Center, Cooperative Institute for Research in the Environmental Sciences, Campus Box 449, University of Colorado, Boulder, CO 80309-0449.]

_ 1996b: Northern Hemisphere EASE-grid weekly snow cover and sea ice content. Volume 2.0: January 2, 1978-September 3 1995. [Available from National Snow and Ice Data Center, Cooperative Institute for Research in the Environmental Sciences, Campus Box 449, University of Colorado, Boulder, CO 80309 0449.]

Oleson, K., and G. B. Bonan, 2000: The effects of remotely-sensed plant functional type and leaf area index on simulations of boreal forest surface fluxes by the NCAR land surface model. J. Hydrometeor., 1, 431-446.

Robinson, D. A., K. F. Dewey, and R. R. Heim Jr., 1993: Global snow cover monitoring: An update. Bull. Amer. Meteor. Soc., 74, 1689-1696.

Schlosser, C. A., A. Robock, K. Y. Vinnikov, N. A. Speranskaya, and Y. Xue, 1997: 18-year land surface hydrology model simulations for a midlatitude grassland catchment in Valdai, Russia. Mon Wea. Rev., 125, 3279-3296.

— , and Coauthors, 1998: Simulations of a boreal grassland hydrology at Valdai, Russia: PILPS phase 2(d). COLA Rep. 61 , 47 pp. [Available from Center for Ocean-Land-Atmosphere Studies, 4041 Powder Mill Road, Suite 302, Calverton, MD 20705.]

Sellers, P. J., J. A. Berry, G. J. Collatz, C. B. Field, and F. G. Hall, 1992: Canopy reflectance, photosynthesis, and transpiration. III. A reanalysis using improved leaf models and a new canopy integration scheme. Remote Sens. Environ., 42, 187-216.

- , and Coauthors, 1996: A revised land surface parameterization
(SiB2) for atmospheric GCMs. Part I: Model formulation. J. Climate, 9, 676-705.

Sitch, S., 2000: The role of vegetation dynamics in the control of atmospheric $\mathrm{CO}_{2}$ content. Ph.D. dissertation, Lund University, 213 pp. [Available from Department of Ecology/Plant Ecology, Ecology Building, S-223 62 Lund, Sweden.]

Smith, T. M., H. H. Shugart, and F. I. Woodward, 1997: Plant Functional Types: Their Relevance to Ecosystem Properties and Global Change. Cambridge University Press, 369 pp.

Tilley, J. S., and A. H. Lynch, 1998: On the applicability of current land surface schemes for Arctic tundra: An intercomparison study. J. Geophys. Res., 103D, 29 051-29 063.

Vinnikov, K. Y., A. Robock, N. A. Speranskaya, and C. A. Schlosser, 1996: Scales of temporal and spatial variability of midlatitude soil moisture. J. Geophys. Res., 101D, 7163-7174.

Willmott, C. J., and K. Matsuura, 1995: Smart interpolation of annually averaged air temperature in the United States. J. Appl. Meteor., 34, 2577-2586.

_ , and S. M. Robeson, 1995: Climatologically aided interpolation (CAI) of terrestrial air temperature. Int. J. Climatol., 15, 221229

—_, and K. Matsuura, cited 2000: Terrestrial air temperature and precipitation: Monthly and annual climatologies. [Available online at http://climate.geog.udel.edu/ climate.]

Woodward, F. I., and W. Cramer, 1996: Plant functional types and climatic changes: Introduction. J. Veg. Sci., 7, 306-308.

Wu, W., and A. H. Lynch, 2000: Response of the seasonal carbon cycle in high latitudes to climate anomalies. J. Geophys. Res. 105D, 22 897-22 908.

Yang, Z.-L., R. E. Dickinson, A. Henderson-Sellers, and A. J. Pitman, 1995: Preliminary study of spin-up processes in land surface models with the first stage data of Project for Intercomparison of Land Surface Parameterization Schemes Phase 1(a). J. Geophys. Res., 100D, 16 553-16 578.

Zeng, X., 2001: Global vegetation root distribution for land modeling. J. Hydrometeor., 2, 525-530.

—- M. Shaikh, Y. Dai, R. E. Dickinson, and R. Myneni, 2002: Coupling of the Common Land Model to the NCAR Community Climate Model. J. Climate, 15, 1832-1854. 
Copyright $\odot 2002$ EBSCO Publishing 